\title{
Evaluation of the Frequency for Gas Sampling for the High Burnup Confirmation Data Project
}

Fuel Cycle Research \& Development

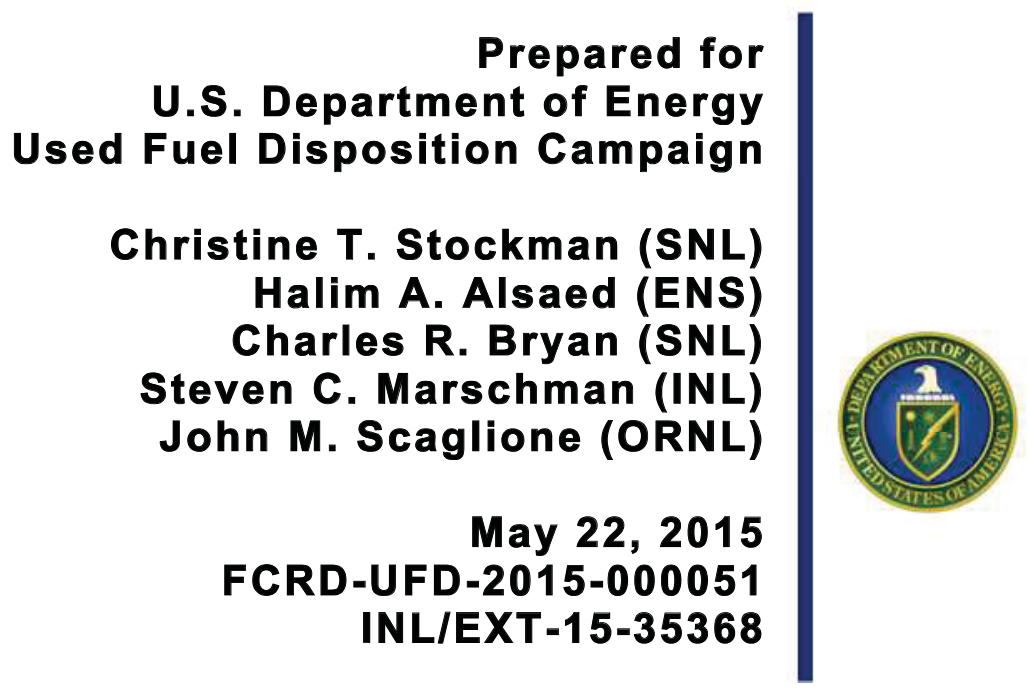




\section{Disclaimer}

This information was prepared as an account of work sponsored by an agency of the U.S. Government. Neither the U. S. government nor any agency thereof, nor any of their employees, makes any warranty, expressed or implied, or assumes any legal liability or responsibility for the accuracy, completeness, or usefulness, of any information, apparatus, product, or process disclosed, or represents that its use would not infringe privately owned rights. References herein to any specific commercial product, process, or service by trade name, trade mark, manufacturer, or otherwise, does not necessarily constitute or imply its endorsement, recommendation, or favoring by the U.S. Government or any agency thereof. The views and opinions of authors expressed herein do not necessarily state or reflect those of the U.S. Government or any agency thereof. 
FCRD-UFD-2015-000051

INL/EXT-15-35368

\title{
Evaluation of the Frequency for Gas Sampling for the High Burnup Confirmation Data Project
}

\author{
Christine T. Stockman \\ Halim A. Alsaed \\ Charles R. Bryan \\ Steven C. Marschman \\ John M. Scaglione
}

Revision 0

May 22, 2015

Idaho National Laboratory

Idaho Falls, Idaho 83415

http://www.inl.gov

Prepared for the

U.S. Department of Energy

Office of Used Nuclear Fuel Disposition Research and Development Under DOE Idaho Operations Office Contract DE-AC07-05ID14517 
This page intentionally left blank. 


\section{Evaluation of the Frequency for Gas Sampling for the High Burnup Confirmation Data Project}

FCRD-UFD-2015-00051

INL/EXT-15-35368

\section{Revision 0}

May 22, 2015

Peer Review:

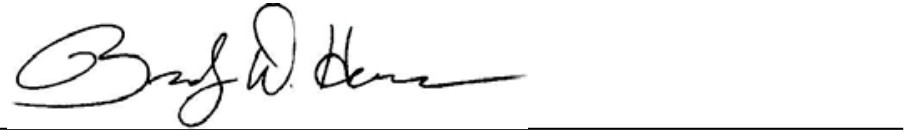

Brady D. Hanson

Pacific Northwest National Laboratory

\section{Concurrence:}

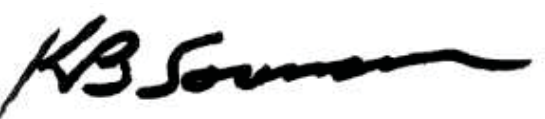

Ken B. Sorenson, S\&T Control Account Manager

Sandia National Laboratory

Submitted by:

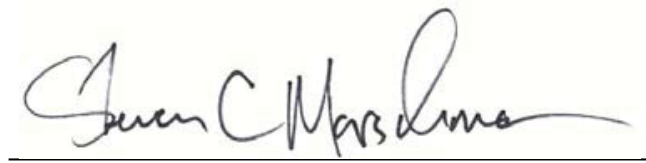

Steven C. Marschman

Idaho National Laboratory
May 22, 2015

Date

May 22, 2015

Date

May 22, 2015

Date 
This page intentionally left blank. 


\section{EXECUTIVE SUMMARY}

This report fulfills the M2 milestone M2FT-15IN0802013, "Evaluation of the Frequency for Gas Sampling for the High Burnup Storage Demonstration Project" under Work Package FT-15IN080201, "ST Field Demonstration Support - INL".

This report provides a technically based gas sampling frequency strategy for the High Burnup (HBU) Confirmatory Data Project. The evaluation of: 1) the types and magnitudes of gases that could be present in the project cask and, 2) the degradation mechanisms that could change gas compositions culminates in an adaptive gas sampling frequency strategy. This adaptive strategy is compared against the sampling frequency that has been developed based on operational considerations.

Gas sampling will provide information on the presence of residual water (and byproducts associated with its reactions and decomposition) and breach of cladding, which could inform the decision of when to open the project cask.

\section{Initial Condition}

After drying (using the vacuum drying process as opposed to the forced helium dehydration process), sealing, leak testing, and backfilling the cask with high purity helium, there may be two types of gases within the cask cavity: 1) fission gases (e.g., ${ }^{85} \mathrm{Kr}$ and ${ }^{134} \mathrm{Xe}$ ) released from breached fuel rods, and 2) residual water and its decomposition products formed by corrosion or radiolysis (e.g., $\mathrm{H}_{2}$ and $\mathrm{O}_{2}$ ). The initial conditions relevant to gas sampling frequency will be established after the cask has been backfilled with helium while the cask is inside the North Anna decontamination building.

\section{Gas Types, Magnitudes, and Detection Limits}

The minimum detectable concentration of ${ }^{85} \mathrm{Kr}$ without using high sensitivity measurement methods is less than one $\mathrm{pCi} / \mathrm{cm}^{3}$ and that of ${ }^{134} \mathrm{Xe}$ by new mass spectrometers is on the order of a few $\mathrm{ppb}$. At these detection limits, even if as little as $1 \%$ of fission gases in a single pellet were to be released, ${ }^{85} \mathrm{Kr}$ and ${ }^{134} \mathrm{Xe}$ would be detectable (assuming the gas is uniformly distributed within the cask). Therefore, potential ${ }^{85} \mathrm{Kr}$ and ${ }^{134} \mathrm{Xe}$ concentrations (initial and subsequent due to potential cladding failures) will be detectable with standard measurement methods, and the frequency of sampling need not be limited by a cladding failure threshold and associated ${ }^{85} \mathrm{Kr}$ and/or ${ }^{134} \mathrm{Xe}$ concentrations. The detectable concentration of water without using high sensitivity measurement methods is about one part per million (ppm). If the NRC drying guidelines are followed, the total unbound water within the cask should be below 0.25 volume percent which is about 11 parts per thousand, an amount easily detected in a gas sample. Thus, the frequency of sampling need not be impacted by a detection limit for water.

\section{Gas Distribution and Sampling Location}

The potential for gas segregation, which would confound the collection of a representative gas sample, is evaluated in this report. It is concluded that neither gravitational settling nor thermal diffusion would result in any significant gas segregation. Therefore, sampling the gas from the top of the project cask will provide a reasonably representative concentration for ${ }^{85} \mathrm{Kr},{ }^{134} \mathrm{Xe}, \mathrm{H}_{2} \mathrm{O}, \mathrm{O}_{2}$, and $\mathrm{H}_{2}$ throughout the cask.

\section{Degradation Mechanisms That Could Change Gas Compositions}

The degradation mechanisms for the components within the cask are evaluated for any information that could be gained from gas sampling and may be useful for informing component performance predictive capabilities. The degradation mechanisms are evaluated in two groups: those that potentially degrade the unbreached cladding, and those that potentially degrade the other internal components (assembly hardware, basket, and neutron poisons). The results for cladding are shown in Table ES-1. For cladding, the only information that can be gained is related to cladding breach. If breach occurs, the cause of a breach may be 
weakly correlated to a few degradation mechanisms (DHC, fission product attack, and creep). This weak correlation, even if established, would still not provide any data to inform predictive models (which do not currently fully exist) for the degradation mechanisms. The degradation mechanisms of the other internal components (assembly hardware, basket, and neutron poisons) that could influence gas composition are oxidation and corrosion, which could consume water and its degradation products $\mathrm{O}_{2}$ and $\mathrm{H}_{2}$. While gas sampling may provide the total consumption rates of these gases, it cannot provide the fraction that is consumed by each component or the amount of degradation experienced by each component. Therefore, the predictive capability of oxidation related degradation mechanisms of these components could not be informed by gas sampling.

Table ES-1. Cladding Related Degradation Mechanisms that could Influence the in-Cask Gases.

\begin{tabular}{|l|c|c|c|}
\hline Degradation Mechanism & $\begin{array}{c}\text { Could be affected } \\
\text { by presence of } \mathbf{H}_{2} \mathbf{O}, \\
\mathbf{O}_{\mathbf{2}} \text {, and } \mathbf{H}_{\mathbf{2}} \text { ? }\end{array}$ & $\begin{array}{c}\text { Could cause release of } \\
\text { fission product gases } \\
\text { from fuel rods? }\end{array}$ & $\begin{array}{c}\text { Could sampling be } \\
\text { informative for } \\
\text { degradation mechanism? }\end{array}$ \\
\hline Fuel restructuring/swelling & No & Yes & No \\
\hline $\begin{array}{l}\text { Fission product attack on } \\
\text { cladding }\end{array}$ & No & Yes & Yes \\
\hline $\begin{array}{l}\mathrm{H}_{2} \text { effects: embrittlement } \\
\text { and reorientation }\end{array}$ & No & No & No \\
\hline $\begin{array}{l}\mathrm{H}_{2} \text { effects: delayed hydride } \\
\text { cracking (DHC) }\end{array}$ & No & Yes & Yes \\
\hline Oxidation and corrosion & Yes & No & No \\
\hline Creep & No & Yes & Yes \\
\hline
\end{tabular}

\section{Gas Sampling Frequency Strategy}

The frequency of sampling to detect the presence and rate of change in gases should be adaptive. An early (within about a year) sample is recommended to be taken after the cask has been moved to the ISFSI pad to confirm the determination of adequate drying $(<0.25$ volume percent water) or to evaluate water concentration if it was above the limit during initial sampling. If water concentration remains at or above the 0.25 volume percent threshold at one year, then the sampling strategy should be revised based on the magnitude of detected gases, which could be indicative of the presence of waterlogged components. If the sample taken at one year indicates that the $\mathrm{H}_{2} \mathrm{O}, \mathrm{O}_{2}$, and $\mathrm{H}_{2}$ concentrations have dropped (or none were detected), then no additional sampling for these gases is warranted within the 10-year project period.

If the early sampling indicates the presence of fission product gases, then failed rods may have been loaded into the cask or rods may have failed during drying, and the sampling frequency strategy should be revised. If the early sampling does not indicate the presence of fission product gases (i.e., all rods are intact), then the frequency of gas sampling would be based on the degradation processes described in Table ES-1. Some processes that are only expected to operate early, due either to the presence of water (oxidation and corrosion) or due to high temperatures (creep, fission product attack and possibly DHC) may occur during the 10-year project period. Other processes operate later as the temperature drops, such as hydride embrittlement, which occurs as the temperature drops below the ductile-to-brittle transition temperature (DBTT), and are less likely to occur during 10 years. If an off-normal event such as an earthquake occurs, the sampling strategy should be reevaluated at that time. 
Because sampling frequency needs to be adaptive based on the initial conditions and subsequent sampling results, the sampling needs and frequencies are presented in the form of an event tree illustrated in Figure ES-1.

\begin{tabular}{|c|c|c|c|c|c|}
\hline $\begin{array}{c}\text { Initial sampling } \\
\text { indicates } \\
\text { presence of } \\
\text { fission gases }\end{array}$ & $\begin{array}{c}\text { Cladding } \\
\text { temperature is } \\
\text { significantly } \\
\text { higher than } \\
\text { expected }\end{array}$ & $\begin{array}{c}\text { Initial sampling } \\
\text { indicates } \\
\text { presence of } \mathrm{H}_{2} \mathrm{O}, \\
\mathrm{H}_{2}, \text { or } \mathrm{O}_{2}\end{array}$ & $\begin{array}{c}\text { Cladding is below } \\
\text { ductile-to brittle } \\
\text { transition } \\
\text { temperature } \\
\text { (DBTT) }\end{array}$
\end{tabular}$\quad$ Recommended Sampling Frequency

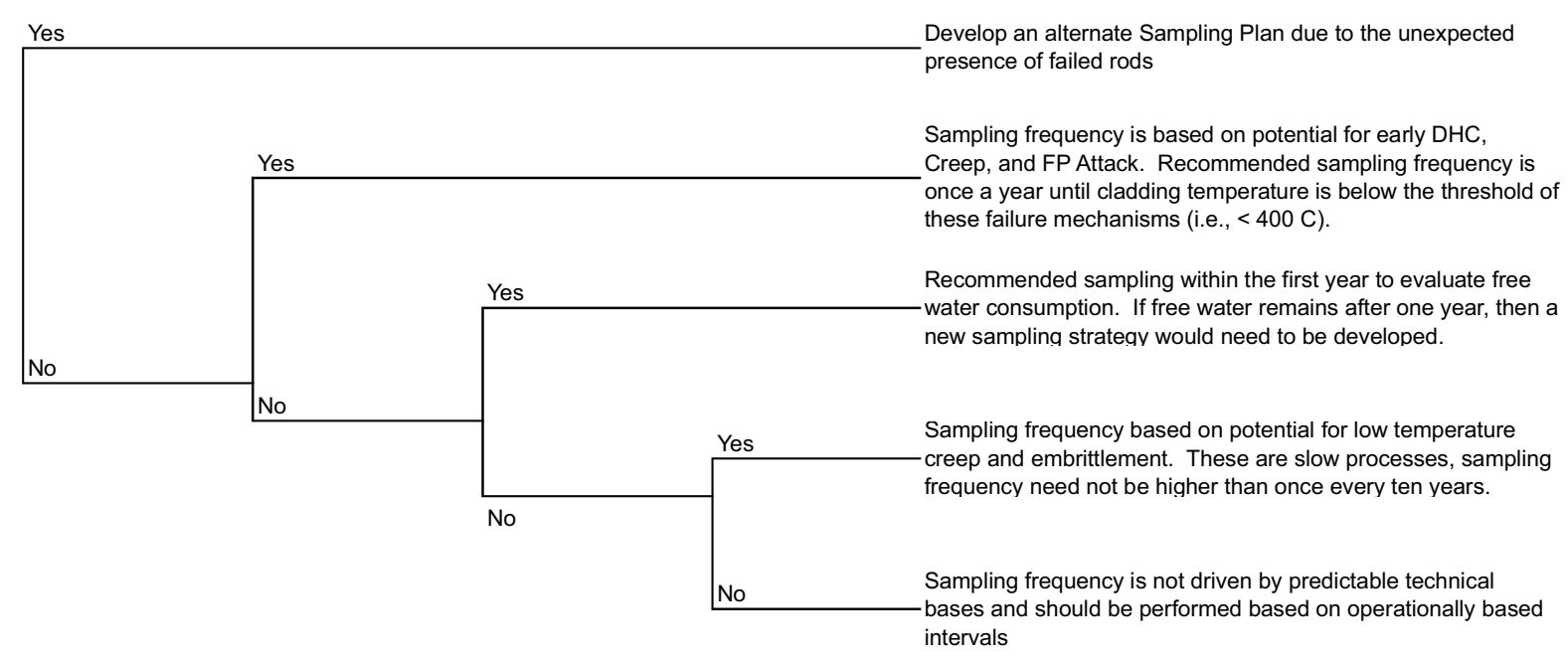

Note: If fission gases are detected during any sampling cycle, a new sampling strategy should be developed due to the presence of failed cladding

Figure ES-1. Gas Sampling Strategy Event Tree.

\section{Comparison of Technically Based and Operationally Based Gas Sampling Frequency Strategies}

The operationally based gas sampling strategy calls for sampling the cask four times (shortly after loading, at about one year, approximately three years after the one year sampling, and at ten years prior to shipping the cask). The evaluation presented in this report concludes that there are no technical reasons to drive a specific sampling frequency unless an unexpected condition occurs (discovery of failed fuel rods during initial sampling, cladding temperatures above limits, inadequate drying, and off-normal/accident conditions). Not only are these conditions generally not expected, the occurrence of these conditions specifically for the project cask is remote given the loading requirements, inspections, testing, and detailed predictive analyses associated with the HBU Confirmatory Data Project. Therefore, the operationally based sampling frequency is consistent with the technical evaluation presented in this report and reflects the bottom branch of the event tree illustrated in Figure ES-1. 
This page intentionally left blank. 


\section{CONTENTS}

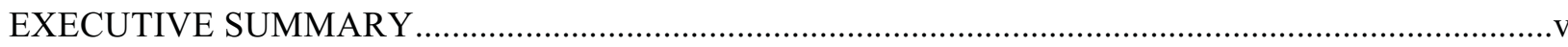

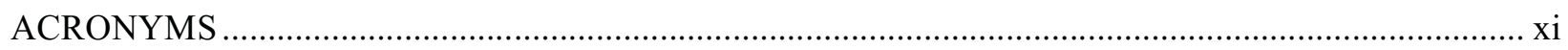

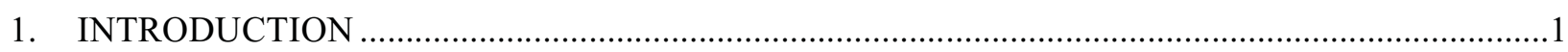

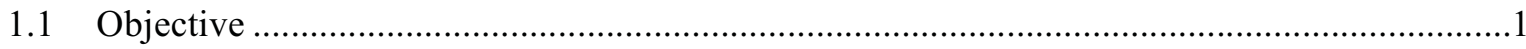

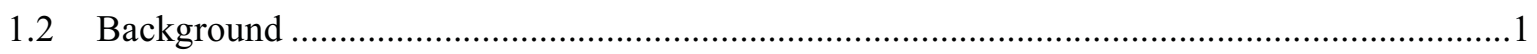

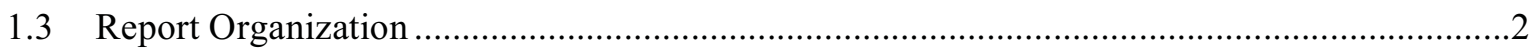

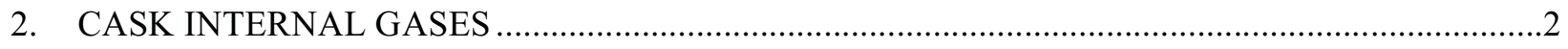

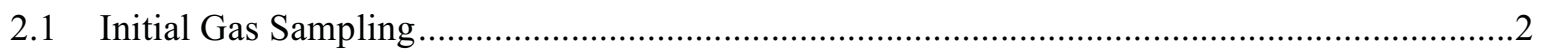

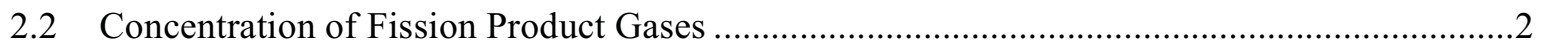

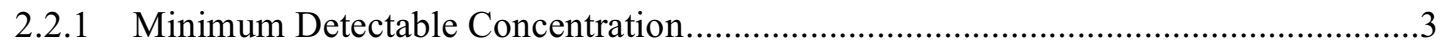

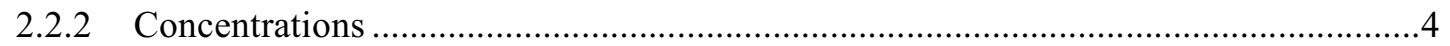

2.2.3 Impact of Potential Fission Gas Concentrations and Detectability Limits on

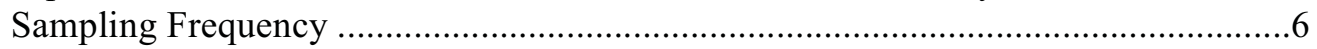

2.2.4 Other Information that Determination of Fission Gas Concentrations May

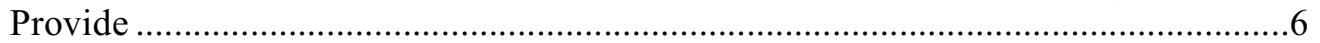

2.3 Concentration of Water and its Corrosion/Decomposition Products .....................................

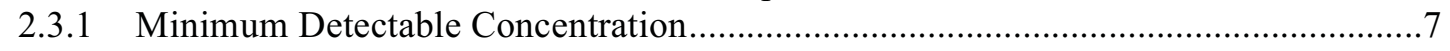

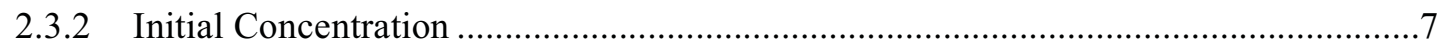

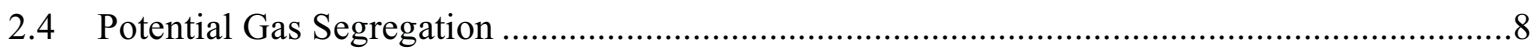

3. EVALUATION OF THE DEGRADATION MECHANISMS THAT COULD INFLUENCE

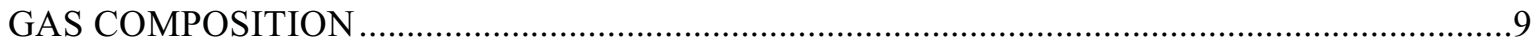

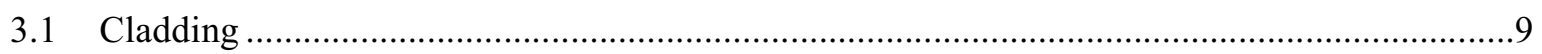

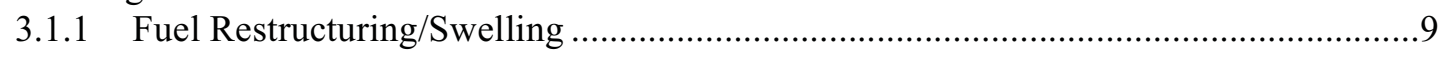

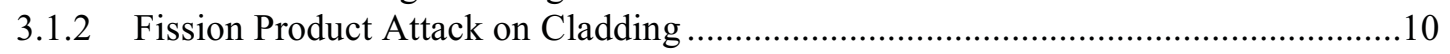

3.1.3 Cladding $\mathrm{H}_{2}$ Effects: Embrittlement and Reorientation ..........................................10

3.1.4 Cladding $\mathrm{H}_{2}$ Effects: Delayed Hydride Cracking .............................................. 10

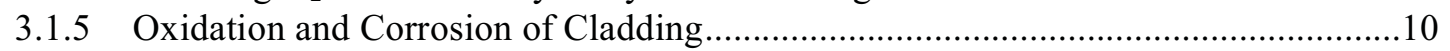

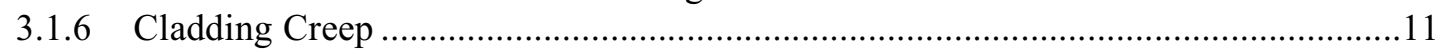

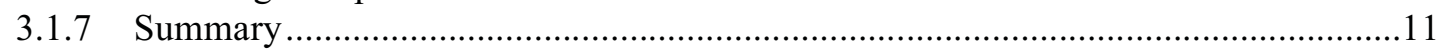

3.2 All Other Internal SSCs (Assembly Hardware, Baskets and Neutron Poisons) .....................12

4. GAS SAMPLING FREQUENCY STRATEGY ..............................................................................12

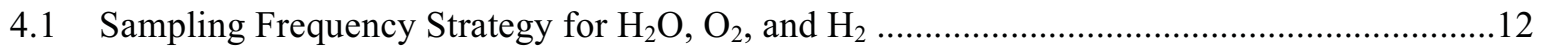

4.2 Sampling Frequency Strategy for Fission Gases............................................................12

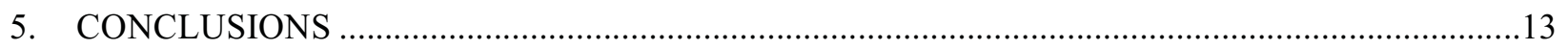

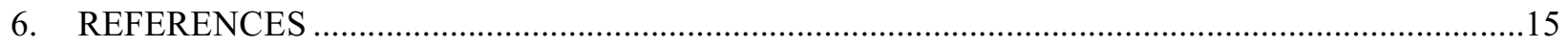

APPENDIX A: Possible Segregation of Gases in the Project Cask ........................................................17 


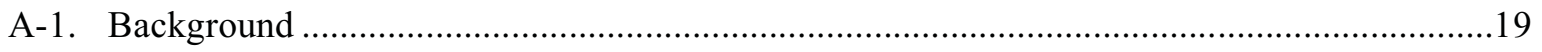

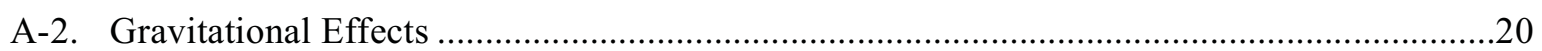

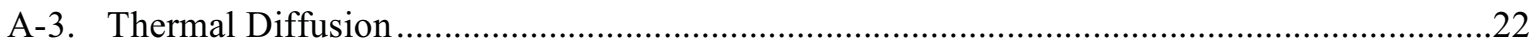

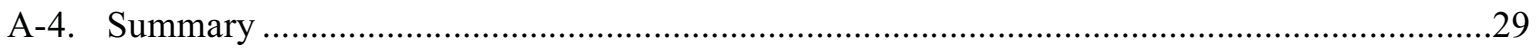

\section{FIGURES}

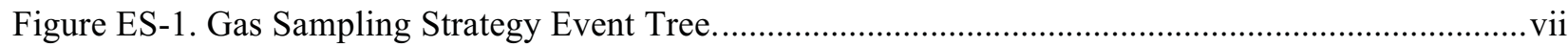

Figure 2-1. Minimum Number of Failed Rods as a Function of ${ }^{85} \mathrm{Kr}$ Concentration. ................................. 7

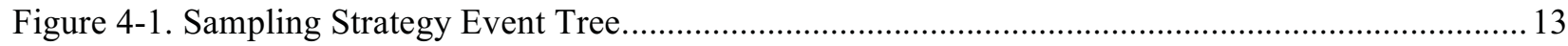

Figure A-1. Schematic of the TN-32 storage cask to be used in the project. ...........................................20

Figure A-2. Compositional gradient required in the project cask for $\mathrm{Kr}$ detection by headspace gas

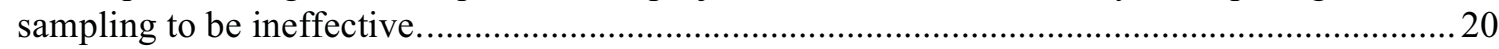

Figure A-3. Schematic of experimental setup used to measure gas separation by thermal diffusion. .........23

Figure A-4. Degree of separation as a function of temperature difference, for a $\mathrm{H}_{2}-\mathrm{N}_{2}$ mixture

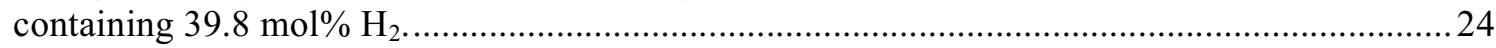

Figure A-5. Degree of separation as a function of temperature difference, for mixtures of (1) He-Ne

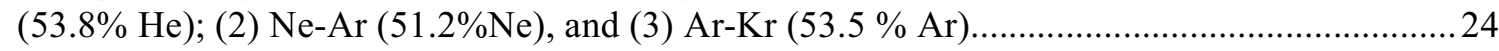

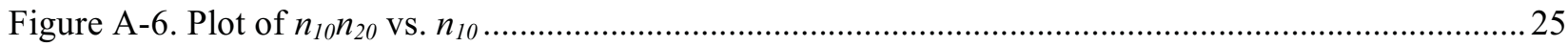

Figure A-7. Degree of separation as a function of gas phase composition, for mixtures of (1) $\mathrm{Kr}-\mathrm{He}$,

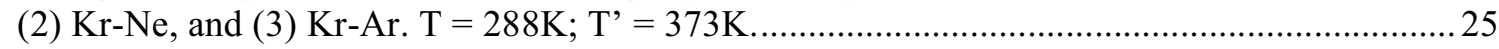

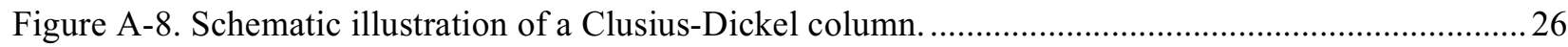

Figure A-9. Schematic illustrating the compositional separation in a Clusius-Dickel column by the

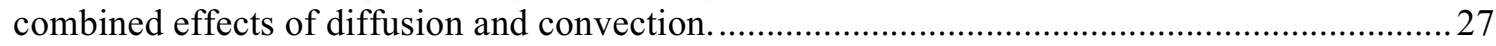

Figure A-10. Schematic of the project cask, showing predicted convection pattern................................28

Figure A-11. Cask schematic, showing that basket walls prevent diffusive exchange between the rising and falling arms of the convection cell.

\section{TABLES}

Table ES-1. Cladding Related Degradation Mechanisms that could Influence the in-Cask Gases. vi

Table 2-1. Parameters Relevant to Calculating Potential ${ }^{85} \mathrm{Kr}$ and ${ }^{134} \mathrm{Xe}$ Concentrations in the Project Cask.

Table 2-2. Calculated ${ }^{85} \mathrm{Kr}$ and ${ }^{134} \mathrm{Xe}$ content of the 25 Sister Rods at possible loading and unloading times.

Table 3-1. Cladding Related Degradation Mechanisms that could Influence the in-Cask Gases. 


\section{ACRONYMS}

BSC

CFD

DBTT

DHC

DOE

DOE-NE

EPRI

GWd

HBU

INL

ISFSI

LWR

MTHM

NRC

PCI

PCMI

PNNL

PWR

SNF

SNL

$\mathrm{SCC}$

$\mathrm{SSC}$

UFDC

UNF

Zircaloy
Bechtel SAIC Co. LLC

computational fluid dynamics

ductile to brittle transition temperature

delayed hydride cracking

U.S. Department of Energy

U.S. Department of Energy Office of Nuclear Energy

Electric Power Research Institute

gigawatt-day

high burnup

Idaho National Laboratory

independent spent fuel storage installation

light-water reactor

metric tons of heavy metal

U.S. Nuclear Regulatory Commission

pellet-clad interaction

pellet cladding mechanical interaction

Pacific Northwest National Laboratory

pressurized water reactor

spent nuclear fuel

Sandia National Laboratories

stress corrosion cracking

structure, system, and component

Used Fuel Disposition Campaign

used nuclear fuel

zirconium alloy 
This page intentionally left blank. 


\section{EVALUATION OF THE FREQUENCY FOR GAS SAMPLING FOR THE HIGH BURNUP CONFIRMATION DATA PROJECT}

\section{INTRODUCTION}

\subsection{Objective}

The objective of this report is to provide a technically based gas sampling frequency strategy for the High Burnup (HBU) Confirmatory Data Project (here called the Project). As stated in the test plan for the Project "The main goals of the proposed test are to provide confirmatory data for model improvement, provide input to future SNF [spent nuclear fuel] dry storage cask design, support license extensions for Independent Spent Fuel Storage Installations (ISFSIs), and support transportation licensing for high burnup SNF."

This report evaluates the following:

1. The types, magnitudes, and possible compositional variation of gases that could be present in a used nuclear fuel (UNF) cask.

2. The conditions within the cask that could be evaluated via the extraction of a gas sample from the cask.

3. The cask component system performance characteristics that could be deduced from a gas sample.

4. The conditions under which the gas sampling frequency would need to be re-evaluated.

\subsection{Background}

A contract was awarded to the Electric Power Research Institute (EPRI) to lead a project team ${ }^{\text {a }}$ to develop the plan for and implement the engineering-scale demonstration called the HBU Confirmatory Data Project, which will collect data from a dry storage cask containing HBU UNF. The Project test plan submitted to the Department of Energy (DOE) Used Fuel Disposition Campaign (UFDC) on February 27, 2014 (EPRI 2014) indicated that data will be collected prior to loading the UNF, during loading and drying, for a short period while the cask remains in the building, while the cask is on the ISFSI pad, and after the cask is unloaded. Sampling the gases within the cask will provide a subset of the data. Such sampling may provide information on:

1. The environmental conditions that could impact the performance of structures, systems, and components (SSCs). These conditions include the presence of water or oxygen within the cask.

2. Changes due to degradation of the internal components. For example, presence of fission gases could indicate cladding failure.

An operationally based gas sampling strategy has been proposed. This strategy calls for sampling the cask four times (shortly after loading, at about one year, approximately three years after the one year sampling, and at ten years prior to shipping the cask).

\footnotetext{
${ }^{\mathrm{a}}$ The EPRI team includes AREVA Federal Services, Transnuclear (TN), Dominion Virginia Power, AREVA Fuels, and Westinghouse Fuels.
} 


\subsection{Report Organization}

In order to perform the necessary evaluations and address the objective discussed in Section 1.1, this report is structured as follows:

- Section 2 discusses the gas constituents that could indicate degradation of the internal components and those that could impact the performance of SSCs. This section also discusses the initial conditions and the minimum extent of failure (e.g., drying failure, cladding failure) that could result in detectable quantities of the gases of interest, and whether gas segregation is likely to complicate the gas sampling process.

- Section 3 presents an evaluation of the degradation mechanisms that could influence gas composition. This section also discusses the likelihood of related failures including their precursors and timing of occurrence.

- Section 4 presents the strategy for sampling frequency. Because sampling frequency will likely be contingent on the results of the initial conditions established within the first few weeks, the follow-on sampling needs and frequencies are presented in the form of an event tree.

\section{CASK INTERNAL GASES}

After drying, sealing, leak testing, and backfilling the cask with high purity helium, there may be two other types of gases within the cask cavity: 1) fission gases released from breached fuel rods, and 2) residual water and its decomposition products formed by corrosion or radiolysis (e.g., $\mathrm{H}_{2}$ and $\mathrm{O}_{2}$ ). The test plan for the project outlines the drying procedure and initial sampling for these two types of gases. The relevant discussions from the test plan are summarized in Section 2.1. To address the question of whether potential concentrations and detection limits influence the gas sampling strategy, detection limits and possible concentrations of two fission gases, and water (as well as $\mathrm{H}_{2}$ and $\mathrm{O}_{2}$ ) are discussed in Sections 2.2 and 2.3, respectively. Section 2.4 summarizes a detailed discussion of the potential for gas segregation within the cask that is provided in Appendix A.

\subsection{Initial Gas Sampling}

The initial conditions relevant to gas sampling frequency will be established within the first few weeks after the cask has been loaded. Initial gas sampling will be performed while the cask is inside the North Anna decontamination building within two weeks after the cask has been loaded, dried (using the vacuum drying process as opposed to the forced helium dehydration process), backfilled with helium, leak tested, and sealed. The initial gas sampling will determine if fission gases, water vapor, oxygen, or hydrogen are present. The two-week thermal transient period after drying is considered to be a reasonable period for which to monitor the cask cavity atmosphere for evidence of fuel failure during or immediately after cask drying (fission product gases), oxidizing gas, and evidence of residual moisture. It is assumed that this is the period of time when the cask reaches its initial dry storage steady state temperature profiles.

\subsection{Concentration of Fission Product Gases}

The concentration of fission product gases would impact the sampling frequency strategy if there were thresholds that could correlate release rates of fission product gases (number of failed rods, types of failure, and gas release fractions) with minimum detectable concentrations. For this analysis, two fission gases are selected $\left({ }^{85} \mathrm{Kr}\right.$ and $\left.{ }^{134} \mathrm{Xe}\right) .{ }^{85} \mathrm{Kr}$ can be detected at very low concentrations by gamma spectroscopy methods and more recently by modern gas mass spectroscopy. A large fraction of the Xe produced in reactor is ${ }^{134} \mathrm{Xe}$, which is known to be "observationally stable" (i.e., the decay rate is so slow such that a half-life has not been determined). Xe concentration is easily measured using modern gas mass 
spectroscopy. Because ${ }^{134} \mathrm{Xe}$ is stable, if a fuel rod fails the concentration of ${ }^{134} \mathrm{Xe}$ in the cask cannot decrease and can only increase as additional Xe is released from that rod or if more fuel rods fail. Because there are few reactions possible with Xenon at the temperature of the cask interior, the concentration will decrease little with time (i.e. surface adsorption might reduce the gas phase concentration slightly). Thus, the presence of Xe can be a good indicator of a fuel rod breach.

The minimum detectable concentrations of ${ }^{85} \mathrm{Kr}$ and ${ }^{134} \mathrm{Xe}$ are discussed Section 2.2 .1 . The potential ${ }^{85} \mathrm{Kr}$ and ${ }^{134} \mathrm{Xe}$ concentrations and associated cladding failure scenarios are discussed in Section 2.2.2. If the minimum detectable ${ }^{85} \mathrm{Kr}$ or ${ }^{134} \mathrm{Xe}$ concentration is extremely low such that it would be reached with minimal cladding failure and gas release fraction, then the frequency of sampling need not be limited by a cladding failure threshold and associated ${ }^{85} \mathrm{Kr}$ and/or ${ }^{134} \mathrm{Xe}$ concentration.

\subsubsection{Minimum Detectable Concentration}

\subsubsection{1 $\quad{ }^{85} \mathrm{Kr}$ Minimum Detectable Concentration}

The minimum detectable concentration of ${ }^{85} \mathrm{Kr}$ is dependent upon several factors including:

1. Volume and geometry of sample

2. Presence of other radionuclides

3. Measurement method, equipment sensitivity and ability to isolate background radiation.

Based on the decay time for the UNF assemblies in the storage cask (over 5 years), ${ }^{85} \mathrm{Kr}$ is the only gaseous radionuclide with relatively significant activity. Therefore, the impact of the presence of other gaseous radionuclides on the minimum detectable activity of ${ }^{85} \mathrm{Kr}$ is expected to be relatively insignificant.

${ }^{85} \mathrm{Kr}$ concentrations in the Castor V/21 cask were measured at various intervals during the Dry Cask Characterization Project using several methods. Section 4.5 of Dry Cask Storage Characterization Project report (EPRI 2002a) states:

"Table 4-3 presents results of the radiochemical analysis of CASTOR V/21 cask gas samples for the years 1994 through 1999. For all of the samples, krypton was analyzed by mass spectrometry and gamma spectroscopy. However, the detection limits for these methods were 0.01 volume \% and $300 \mathrm{pCi} / \mathrm{cm}^{3}\left[\mathrm{pCi}\right.$ is pico $\left.\left(10^{-12}\right) \mathrm{Ci}\right]$, respectively. From 1995 through 1999, radiochemical analyses were also performed by liquid scintillation counting, which is approximately $10^{3}$ times more sensitive than gamma counting. ",

The Dry Cask Storage Characterization Project report (EPRI 2002a) also states in Section 4.2, "The 1985 report identified that ${ }^{85} \mathrm{Kr}$ concentrations in the samples ranged from $<0.02$ to $0.4 \mathrm{pCi} / \mathrm{cc}$, which was marginally detectable in the 1985 analyses, while the ${ }^{14} \mathrm{C}$ concentrations ranged from 0.6 to $7.9 \mathrm{pCi} / \mathrm{cc}$. The amounts of ${ }^{85} \mathrm{Kr}$ and ${ }^{14} \mathrm{C}$ are relatively low and are what would be expected to result from crud, not a leaking fuel rod."

Therefore, it can be concluded that the minimum detectable concentration of ${ }^{85} \mathrm{Kr}$ is well below one $\mathrm{pCi} / \mathrm{cm}^{3}$ without using high sensitivity measurement methods.

\subsubsection{2 $\quad{ }^{134}$ Xe Minimum Detectable Concentration}

Modern gas mass spectrometers have sensitivities as low as $10 \mathrm{ppb}^{\mathrm{c}}$.

\footnotetext{
${ }^{\mathrm{b}} 0.01$ volume $\%{ }^{85} \mathrm{Kr}$ is about $1.4 \times 10^{-4} \mathrm{Ci} / \mathrm{cm}^{3}$ at $68^{\circ} \mathrm{F}$ and 1 atmosphere.

${ }^{\mathrm{c}}$ Specifications for a $\mathrm{Nu}$ eVolution double focusing magnetic sector gas mass spectrometer being installed at INL.
} 


\subsubsection{Concentrations}

Table 2-1 provides relevant data for calculating ${ }^{85} \mathrm{Kr}$ and ${ }^{134} \mathrm{Xe}$ amounts in UNF and potential concentrations in the project cask (TN-32). Note that the fission product amounts in UNF are dependent upon many parameters including burnup, cooling time, initial enrichment, and assembly mass. The values of these parameters for the 25 "sister" rods chosen to establish the baseline for this Project are provided in Table 2-2 along with the results of detailed calculations for each rod. The calculated ${ }^{85} \mathrm{Kr}$ activity/rod ranges from 5.6 to $23 \mathrm{Ci}$ on February 1,2016 and 2.7 to $11 \mathrm{Ci}$ in 2027 . The calculated ${ }^{134} \mathrm{Xe}$ amount/rod ranges from 3.884 to $4.717 \mathrm{grams} / \mathrm{rod}$. In the calculations presented below, intermediate values of $8.54 \mathrm{Ci}$ ${ }^{85} \mathrm{Kr}$ and $4.3 \mathrm{~g}{ }^{134} \mathrm{Xe}$ were chosen for illustration purposes.

Table 2-1. Parameters Relevant to Calculating Potential ${ }^{85} \mathrm{Kr}$ and ${ }^{134} \mathrm{Xe}$ Concentrations in the Project Cask.

\begin{tabular}{|c|c|}
\hline Parameter & Value \\
\hline${ }^{85} \mathrm{Kr}$ fission yield & $\begin{array}{l}0.286+/-0.021 \% \text { per }{ }^{235} \mathrm{U} \text { fission } \\
0.136+/-0.014 \% \text { per }{ }^{239} \mathrm{Pu} \text { fission }\end{array}$ \\
\hline${ }^{85} \mathrm{Kr}$ half-life & 10.756 years \\
\hline${ }^{85} \mathrm{Kr}$ specific activity & $400 \mathrm{Ci} / \mathrm{g}$ \\
\hline${ }^{85} \mathrm{Kr}$ molecular weight & $84.91 \mathrm{~g} / \mathrm{mole}$ \\
\hline Average ${ }^{85} \mathrm{Kr}$ activity per UNF assembly & $\begin{array}{l}3.11 \times 10^{3} \mathrm{Ci} \text { based on a representative assembly with } \\
\text { initial enrichment of } 4.2 \mathrm{wt} . \%{ }^{235} \mathrm{U} \text {, initial MTHM of } \\
0.475 \text {, burnup of } 50 \mathrm{GWd} / \mathrm{MTHM} \text { and cooling for } 10 \\
\text { years (BSC 2007). }\end{array}$ \\
\hline Average ${ }^{85} \mathrm{Kr}$ activity per fuel rod & 8.54 $\mathrm{Ci}$ based on a $17 \times 17$ assembly design ( 264 rods). \\
\hline $\begin{array}{l}\text { Total }{ }^{85} \mathrm{Kr} \text { activity in project cask ( } 32 \\
\text { assemblies) }\end{array}$ & $9.95 \times 10^{4} \mathrm{Ci}$ \\
\hline Assumed ${ }^{134}$ Xe mass per fuel rod & $4.3 \mathrm{~g}$ \\
\hline TN-32 helium fill pressure & $2,230+/-100$ mbar $(2.2$ atmospheres (atm)) \\
\hline Cavity length & 163.25 inch \\
\hline Cavity diameter & 68.75 inch. \\
\hline Assumed average cask temperature & $350^{\circ} \mathrm{C}\left(623^{\circ} \mathrm{K}\right)$ \\
\hline $\begin{array}{l}\text { Assumed void within cask taking into account } \\
\text { space occupied by assemblies and baskets }\end{array}$ & $50 \%$ \\
\hline Gas constant & $8.205736 \times 10^{-5} \mathrm{~m}^{3}$.atm $/$ K.mole \\
\hline Cavity void volume & $4.965 \mathrm{~m}^{3}$ \\
\hline
\end{tabular}


Evaluation of the Frequency for Gas Sampling for the High Burnup Confirmation Data Project May 22, 2015 FCRD-UFD-2015-00051, INL/EXT-15-35368

Table 2-2. Calculated ${ }^{85} \mathrm{Kr}$ and ${ }^{134} \mathrm{Xe}$ content of the 25 Sister Rods at possible loading and unloading times.

\begin{tabular}{|c|c|c|c|c|c|c|c|}
\hline \multicolumn{4}{|c|}{ Assembly } & \multirow{2}{*}{$\begin{array}{c}\text { Rod } \\
\text { ID }\end{array}$} & \multirow{2}{*}{$\begin{array}{c}2 / 1 / 2016 \\
{ }^{85} \mathrm{Kr} \\
(\mathrm{Ci})\end{array}$} & \multirow{2}{*}{$\begin{array}{c}2 / 1 / 2027 \\
{ }^{85} \mathrm{Kr} \\
(\mathrm{Ci})\end{array}$} & \multirow{2}{*}{$\begin{array}{c}\text { Stable } \\
{ }^{134} \mathrm{Xe}(\mathrm{g})\end{array}$} \\
\hline ID & Enrichment & $\begin{array}{c}\text { Burnup } \\
\text { (MWD/ } \\
\text { MTU) }\end{array}$ & $\begin{array}{l}\text { Cooling Time } \\
\text { (years) }\end{array}$ & & & & \\
\hline \multirow{5}{*}{$30 \mathrm{~A}$} & \multirow{5}{*}{4.55} & \multirow{5}{*}{52.0} & \multirow{5}{*}{5.4} & G-9 & 22.540 & 11.092 & 4.255 \\
\hline & & & & K-9 & 22.496 & 11.072 & 4.244 \\
\hline & & & & D-5 & 22.924 & 11.284 & 4.351 \\
\hline & & & & E-14 & 22.980 & 11.312 & 4.365 \\
\hline & & & & P-2 & 21.432 & 10.548 & 3.984 \\
\hline \multirow{4}{*}{$5 \mathrm{~K} 7$} & \multirow{4}{*}{4.55} & \multirow{4}{*}{53.3} & \multirow{4}{*}{9.9} & P-2 & 16.472 & 8.108 & 4.119 \\
\hline & & & & C-5 & 17.800 & 8.760 & 4.562 \\
\hline & & & & K-9 & 17.152 & 8.440 & 4.343 \\
\hline & & & & $\mathrm{O}-14$ & 16.852 & 8.296 & 4.244 \\
\hline \multirow{7}{*}{$6 \mathrm{U} 3$} & \multirow{7}{*}{4.45} & \multirow{7}{*}{52.7} & \multirow{7}{*}{11.7} & $\mathrm{I}-7$ & 15.164 & 7.464 & 4.360 \\
\hline & & & & M-9 & 15.312 & 7.536 & 4.416 \\
\hline & & & & K-9 & 15.216 & 7.488 & 4.380 \\
\hline & & & & L-8 & 15.328 & 7.544 & 4.422 \\
\hline & & & & O-5 & 15.928 & 7.840 & 4.655 \\
\hline & & & & M-3 & 15.792 & 7.772 & 4.603 \\
\hline & & & & P-16 & 14.180 & 6.980 & 3.993 \\
\hline \multirow{3}{*}{$3 \mathrm{~F} 9$} & \multirow{3}{*}{4.25} & \multirow{3}{*}{52.3} & \multirow{3}{*}{14.4} & N-5 & 12.620 & 6.212 & 4.361 \\
\hline & & & & D-7 & 12.288 & 6.048 & 4.210 \\
\hline & & & & P-2 & 11.692 & 5.756 & 3.943 \\
\hline \multirow{2}{*}{$3 \mathrm{D} 8$} & \multirow{2}{*}{4.20} & \multirow{2}{*}{54.9} & \multirow{2}{*}{17.4} & E-14 & 10.992 & 5.412 & 4.717 \\
\hline & & & & B-2 & 9.796 & 4.824 & 4.044 \\
\hline \multirow{2}{*}{$3 \mathrm{~A} 1$} & \multirow{2}{*}{4.00} & \multirow{2}{*}{50.0} & \multirow{2}{*}{21.4} & B-16 & 7.236 & 3.562 & 3.884 \\
\hline & & & & F-5 & 7.572 & 3.726 & 4.124 \\
\hline \multirow{4}{*}{ F35 } & \multirow{2}{*}{3.59} & 570 & 260 & P-17 & 5.572 & 2.743 & 4.620 \\
\hline & & (1.9 & 20.9 & $\mathrm{~K}-13$ & 5.572 & 2.743 & 4.620 \\
\hline & & & Maxim & & 22.980 & 11.312 & 4.717 \\
\hline & & & Minimı & & 5.572 & 2.743 & 3.884 \\
\hline
\end{tabular}

The helium moles in the cask can be determined using the ideal gas law $(\mathrm{PV}=\mathrm{nRT})$.

$$
\begin{aligned}
\mathrm{n} \text { moles of } \mathrm{He} & =\left[(2.2 \mathrm{~atm}) \times\left(4.965 \mathrm{~m}^{3}\right)\right] /\left(8.2 \times 10^{-5} \mathrm{~m}^{3} \mathrm{~atm} \mathrm{~K} \mathrm{~K}^{-1} \mathrm{~mole}^{-1}\right) \times(623 \mathrm{~K}) \\
& =213.67 \text { moles He } \\
\text { Mass of He } & =213.67 \text { moles } \times 4 \mathrm{~g} / \text { mole }=854.67 \mathrm{~g}
\end{aligned}
$$


If a single UNF rod fails and releases $1 \%{ }^{\mathrm{d}}$ of its ${ }^{85} \mathrm{Kr}$ activity, the average volumetric activity concentration in the cask (based on uniform distribution [i.e., no settling]) would be:

$$
\begin{aligned}
\text { Concentration of }{ }^{85} \mathrm{Kr} & =(8.54 \mathrm{Ci} / \mathrm{rod}) \times 0.01 / 4.965 \times 10^{6} \mathrm{~cm}^{3} \\
& =17.2 \text { nano }\left(10^{-9}\right) \mathrm{Ci} / \mathrm{cm}^{3}\left(\mathrm{nCi} / \mathrm{cm}^{3}\right)
\end{aligned}
$$

Using the specific activity of ${ }^{85} \mathrm{Kr}$, the ${ }^{85} \mathrm{Kr}$ mass associated with a release fraction of $1 \%$ from a single rod is:

$$
\begin{aligned}
\text { Mass of }{ }^{85} \mathrm{Kr} & =(8.54 \mathrm{Ci} / \mathrm{rod}) \times 0.01 / 400 \mathrm{Ci} / \mathrm{g} \\
& =2.135 \times 10^{-4} \mathrm{~g}
\end{aligned}
$$

The mass concentration of ${ }^{85} \mathrm{Kr}$ in the cask, assuming homogenous mixing with the helium, would be:

Mass concentration $=2.135 \times 10^{-4} \mathrm{~g}{ }^{85} \mathrm{Kr} / 854.67 \mathrm{~g} \mathrm{He}$

$$
=250 \mathrm{ppb}
$$

Using the same release fraction (1\%), the mass of ${ }^{134} \mathrm{Xe}$ would be:

$$
\text { Mass of }{ }^{134} \mathrm{Xe}=(4.3 \mathrm{~g} / \mathrm{rod}) \times 0.01=0.043 \mathrm{~g}
$$

The mass concentration of ${ }^{134} \mathrm{Xe}$ in the cask, assuming homogenous mixing with the helium, would be:

$$
\begin{gathered}
\text { Mass concentration }=0.043 \mathrm{~g}{ }^{134} \mathrm{Xe} / 854.67 \mathrm{~g} \mathrm{He} \\
=50 \mathrm{ppm}
\end{gathered}
$$

\subsubsection{Impact of Potential Fission Gas Concentrations and Detectability Limits on Sampling Frequency}

As discussed in Section 2.2.1.1, the minimum detectable concentration of ${ }^{85} \mathrm{Kr}$ without using high sensitivity measurement methods is less than a $\mathrm{pCi} / \mathrm{cm}^{3}$, which is four orders of magnitude smaller than the potential concentration in the project cask due to releasing $1 \%$ of the ${ }^{85} \mathrm{Kr}$ in a single rod. Even if as little as $1 \%$ of ${ }^{85} \mathrm{Kr}$ in a single pellet $(\sim 1 \mathrm{~cm}$ in height; $\sim 0.3 \%$ of active fuel height) were to be released, then it would be detectable (assuming the ${ }^{85} \mathrm{Kr}$ gas is uniformly distributed within the cask).

The mass concentration of ${ }^{134} \mathrm{Xe}$ in the cask from a single rod failure (at a conservative fission gas release fraction of 0.01 ) is about $50 \mathrm{ppm}$. Modern gas mass spectrometers have sensitivities as low as $10 \mathrm{ppb}^{\mathrm{e}}$. Thus, the sensitivity of modern gas mass spectrometers is three orders of magnitude greater than needed for Xe analyses. Gas samples could be collected using simple evacuated 1 liter gas sampling vessels. These types of gas samples are routinely shipped by commercial airfreight, and gas samples can be analyzed in less than one day.

\subsubsection{Other Information that Determination of Fission Gas Concentrations May Provide}

The magnitude of the measured ${ }^{85} \mathrm{Kr}$ and/or ${ }^{134} \mathrm{Xe}$ concentrations provides only a lower bound on the number of failed fuel rods as illustrated in Figure 2-1 for potential ${ }^{85} \mathrm{Kr}$ concentrations, which are based on a release fraction of $100 \%$. However, because there is potentially significant variability in release fractions (both prompt immediately after cladding failure and latent due to diffusion and potential fuel restructuring), an upper bound on the number of failed fuel rods cannot be correlated to measured ${ }^{85} \mathrm{Kr}$ and/or ${ }^{134} \mathrm{Xe}$ concentration levels.

\footnotetext{
${ }^{d}$ Release fractions are expected to be significantly higher than 1\%. NUREG-1536 Rev. 1, Section 4.5.4.6 states "The NRC also accepts that a minimum of 100 percent of the fill gas and 30 percent of the significant radioactive gases (e.g., ${ }^{3} \mathrm{H}, \mathrm{Kr}$, and $\mathrm{Xe}$ ) within a ruptured fuel rod is available for release into the cask cavity." It is acknowledged that the $30 \%$ release fraction is intended to be conservatively high; comparatively, $1 \%$ release fraction would be considered conservatively low.

${ }^{\mathrm{e}}$ Specifications for a $\mathrm{Nu}$ eVolution double focusing magnetic sector gas mass spectrometer being installed at INL.
} 


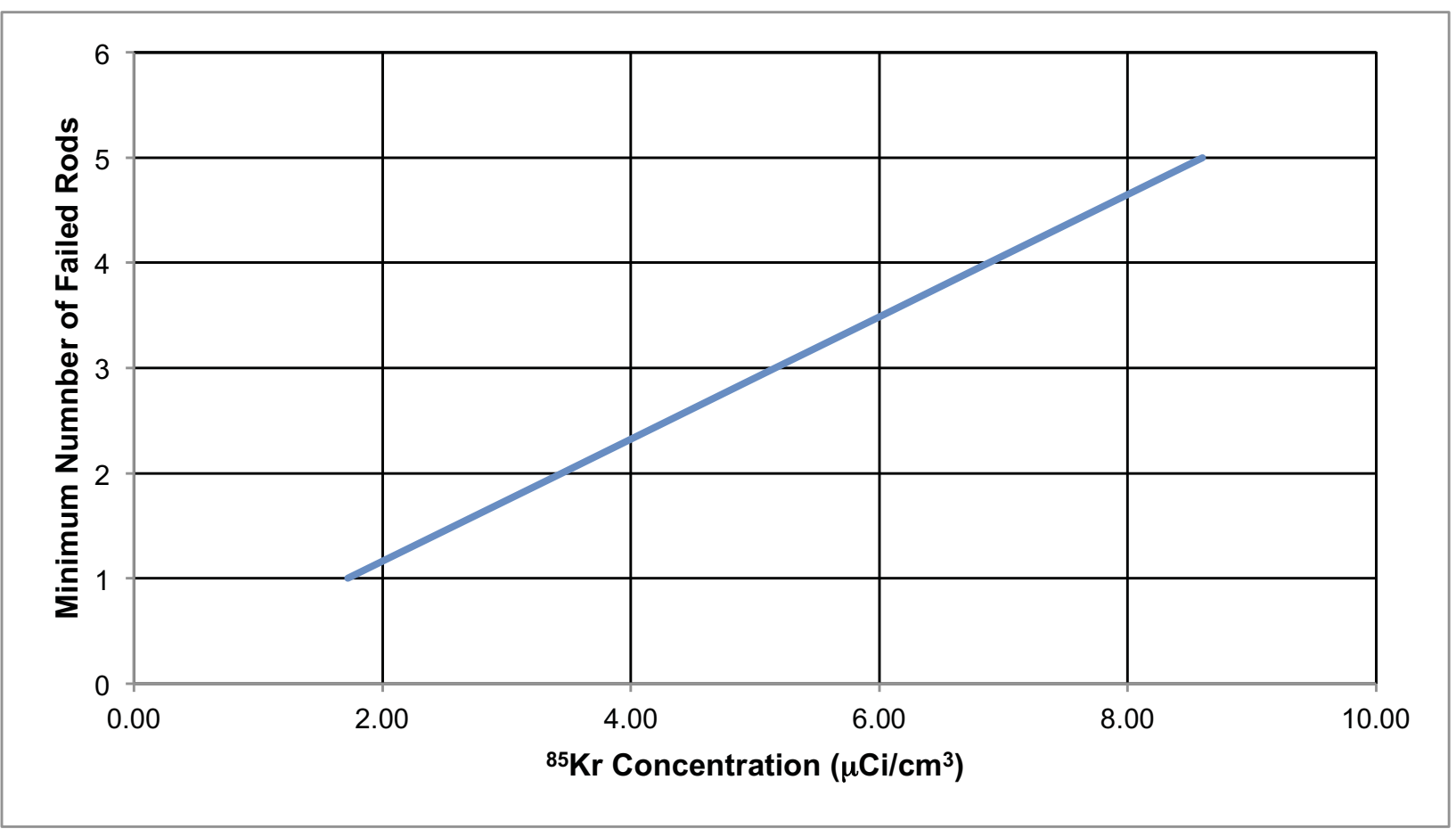

Figure 2-1. Minimum Number of Failed Rods as a Function of ${ }^{85} \mathrm{Kr}$ Concentration.

\subsection{Concentration of Water and its Corrosion/Decomposition Products}

\subsubsection{Minimum Detectable Concentration}

Depending on the method used, very low concentrations of water in helium may be detected - in the ppb to ppm range. Several examples are provided in the white papers presented in the appendixes of the report edited by Marschman (2014). In the white paper by Carter et al. (2014) the following statement was made:

"Gas sample size is dependent on the equipment used to perform the analysis. Assuming the sample is collected at cask pressure (i.e. approximately 2 atm He) and a mass spectrometer with a 25 microliter injection loop is used to analyze the gas sample, a $500 \mathrm{~mL}$ sample would provide a comfortable volume for detection in the ppm range and possibly lower."

\subsubsection{Initial Concentration}

The U.S. Nuclear Regulatory Commission (NRC) does not specify, nor does the test plan clearly describe, a drying procedure. NUREG-1536 (NRC 2010) provides guidance in Sections 9.4.1 and 9.5.1. Section 9.5.1 states:

"The NRC staff has accepted vacuum drying methods comparable to those recommended in PNL6365 (Knoll [and Gilbert], 1987). This report evaluates the effects of oxidizing impurities on the dry storage of light-water reactor (LWR) fuel and recommends limiting the maximum quantity of oxidizing gasses (such as $\mathrm{O}_{2}, \mathrm{CO}_{2}$, and CO) to a total of 1 gram-mole per cask. This corresponds to a concentration of 0.25 volume percent of the total gases for a $7.0 \mathrm{~m}^{3}$ (about $247 \mathrm{ft}^{3}$ ) cask gas volume at a pressure of about $0.15 \mathrm{MPa}(1.5 \mathrm{~atm})$ at $300^{\circ} \mathrm{K}\left(80.3^{\circ} \mathrm{F}\right)$. This 1 gram-mole limit reduces the amount of oxidants below levels where any cladding degradation is expected. 
Moisture removal is inherent in the vacuum drying process, and levels at or below those evaluated in PNL-6365 (about 0.43 gram-mole $\mathrm{H}_{2} \mathrm{O}$ ) are expected if adequate vacuum drying is performed."

If the NRC guidelines are followed, the total unbound water within the cask should be below the 0.25 volume percent limit for all oxidizing gases. A volume percent of 0.25 is 1.1 weight percent or 11 parts per thousand, an amount easily detected in a gas sample. In the project cask with an assumed $50 \%$ void volume, 0.25 volume percent water is 0.53 total moles or 9.6 milliliters liquid water. However, in the unlikely event of an undetected waterlogged rod, the water content of the cask may be higher. As noted in the gap report (Hanson et al. 2012), Kohli et al. (1985) showed that even with large defects and $3 \mathrm{~mm}$ holes drilled in the plenum region of each rod, the rods continued to outgas for about 1000 hours at $325^{\circ} \mathrm{C}$. Since only intact fuel is to be loaded in to the project cask, only rods with very small breaches could be loaded as undetected waterlogged rods, therefore it is unlikely that all water from such rods would be removed during the two weeks the cask is in the building.

As noted by Knoll and Gilbert (1987), there are four potential sources of impurity gases in the helium cover gas in operating casks: 1) impurities based on the purity of the helium cover gas used, 2) air leakage into the cask cavity through the seals between the cask body and primary cover, 3) residual impurity gases remaining in the cask after evacuation to a finite pressure level, and 4) impurity gases introduced into the cask atmosphere after evacuation and backfill because of outgassing from the structural materials and fuel assemblies (This could include release of unbound water from tight places or chemically or physically bound water on any surface.) They indicate that most of the impurities originate from the third and fourth sources, which together are estimated to produce a reactive gas inventory less than the $0.25 \%$ limit they propose. They reviewed the analysis of cover gases for three operating casks: a TN-24P, an MC-10, and an MSF IV, and reported the maximum volume percent values for the impurity gases detected, including: $\mathrm{O}_{2}$ $0.06 \%, \mathrm{H}_{2} \mathrm{O} 0.10 \%$, and $\mathrm{H}_{2} 0.04 \%$. They analyzed the possible reactions of these gases with the cladding and exposed fuel and concluded that at a total oxidizing gas concentration of 0.25 volume percent, degradation of the cladding and fuel would be insignificant unless all of the impurities reacted with the fuel of a breached rod, and the resulting fuel oxidation resulted in fuel swelling and cladding splitting. Because the third and fourth sources of impurities originate within the cask, their inventory will not increase in time, but will decrease as they react with the cask internal metals. At expected cask temperature ranges, the impurity consumption rate will be high due to the high surface area of the metals within the cask relative to the small impurity concentrations. For example, Knoll and Gilbert (1987) estimated a consumption rate of $\mathrm{O}_{2}$ of about $0.002 \mathrm{~mole} / \mathrm{m}^{2}$ cladding per year at $260^{\circ} \mathrm{C}$, thus all $\mathrm{O}_{2}$ would be consumed in less than a year at that temperature.

The recommended limit of 0.25 volume percent for all oxidizing gases, which would include $\mathrm{H}_{2} \mathrm{O}$ and its degradation or decomposition products, is orders of magnitude higher than the ppm-range detection limits.

\subsection{Potential Gas Segregation}

To address the concern that potential gas impurities (e.g. ${ }^{85} \mathrm{Kr}$ ) may segregate from the helium cover gas, thus confounding the collection of a representative gas sample, the potential for gas segregation due to the development of compositional gradients is evaluated in detail in Appendix A. Possible mechanisms that could lead to compositional gradients within a cask include:

1. Gravitational settling of the heavier, denser ${ }^{85} \mathrm{Kr}$ within a stagnant cask. This could conceivably occur immediately after breach of a fuel rod, but a stable compositional gradient cannot be maintained over time, even in a static gas column. Within a convecting gas column, the effects of gravitational settling would be even more rapidly eliminated.

2. Thermal diffusion. Thermal diffusion could result in minor degrees of compositional variation in the gas phase within a stagnant cask, but sufficient separation to affect ${ }^{85} \mathrm{Kr}$ detection is not possible. Conversely, and perhaps counter-intuitively, in a convecting system, the combined effects of thermal diffusion and convection may lead to high degrees of separation, if large variations in temperature and 
the appropriate geometry exist. These conditions do not exist in storage casks, therefore, there is no plausible potential for gas separation.

Thus, sampling the gas phase from the top of the project cask is likely to provide a reasonably representative sample for ${ }^{85} \mathrm{Kr}$ concentration. Possible segregation of the lighter gas impurities $\left(\mathrm{H}_{2} \mathrm{O}, \mathrm{O}_{2}\right.$, and $\mathrm{H}_{2}$ ) is even less likely.

Even though the density of $\mathrm{Kr}$ is approximately 20 times higher than the density of $\mathrm{He}$, gas concentration gradients are not expected in the projects cask. These expectations can be extrapolated to Xe, whose density is only $50 \%$ higher than $\mathrm{Kr}$.

\section{EVALUATION OF THE DEGRADATION MECHANISMS THAT COULD INFLUENCE GAS COMPOSITION}

The degradation mechanisms for the components within the cask that could influence the cask internal gas composition are evaluated for any information that could be gained from gas sampling and may be useful for informing component performance predictive capabilities. The degradation mechanisms are evaluated in two groups: those that potentially degrade the unbreached cladding, and those that potentially degrade the other internal components (assembly hardware, basket, neutron poisons).

\subsection{Cladding}

The presence of $\mathrm{H}_{2} \mathrm{O}$ (with or without $\mathrm{O}_{2}$ and $\mathrm{H}_{2}$ ) indicates residual water is present. The presence of $\mathrm{O}_{2}$ or $\mathrm{H}_{2}$ (without $\mathrm{H}_{2} \mathrm{O}$ ) indicates residual water was present. Although, the presence of $\mathrm{H}_{2} \mathrm{O}, \mathrm{O}_{2}$, and $\mathrm{H}_{2}$ could cause further oxidation of the cladding, it does not provide any information regarding the extent of cladding oxidation or cladding condition.

The presence of ${ }^{85} \mathrm{Kr}$ or ${ }^{134} \mathrm{Xe}$ indicates that cladding has failed sufficiently to release fission product gases. The concentration of ${ }^{85} \mathrm{Kr}$ and ${ }^{134} \mathrm{Xe}$ could provide information on the extent of cladding failure, however, it does not provide direct information on the cause of failure. The cause of failure may be deduced based on other parameters (e.g., temperature)

The cladding related degradation mechanisms identified in the gap analysis report (Hanson et al. 2012) that could influence gas composition are discussed below to identify those that could be informed by gas sampling timing.

\subsubsection{Fuel Restructuring/Swelling}

Fuel Restructuring/Swelling could affect the internal gas composition only if the resulting stress exerted on the cladding causes cladding breach and release of gaseous fission products. The UFDC assigned research needs for this mechanism a low rank because "analyses (e.g., Ferry et al. 2005) have shown that helium production in $\mathrm{UO}_{2}$ fuels is not an issue, even at extended times." (UFDC 2012). The NRC assigned this mechanism a high rank for further research stating:

"In general, pellet swelling can increase stresses on the cladding and can potentially lead to cladding splitting (rupture) due to pellet cladding mechanical interaction [PCMI]. These phenomena have the potential to lead to partial and through-wall cracking of the cladding, resulting in the release of fission gases into the cask environment. Pellet swelling is a degradation phenomena that is operative in a long-term (i.e., >100 years) storage timeframe, due to increased accumulation of helium." (NRC 2012) 
This mechanism is unlikely to occur for decades or centuries, and thus is not applicable to the Project. Therefore, no information on this degradation mechanism is expected from gas sampling.

\subsubsection{Fission Product Attack on Cladding}

The gap report (Hanson et al. 2012) states:

"The phenomenon of pellet-clad interaction (PCI) is fairly well understood. It involves [stress corrosion cracking] SCC of the cladding as a result of the combination of an aggressive environment, a tensile stress, and a susceptible material. In this case, the aggressive environment is caused by the fission products iodine, cesium, and cadmium that are known to promote SCC. ... As the temperatures decrease, so will the rod internal pressure, alleviating much of the tensile stress. Thus, the driving forces for PCI failure will not increase, and, in fact, the stress will decrease with extended storage."

If ${ }^{85} \mathrm{Kr}$ or ${ }^{134} \mathrm{Xe}$ are detected while temperatures are high, fission product attack could be the cause of cladding failure. However, only after the cask is opened and the cladding is examined could this causational relationship be established.

\subsubsection{Cladding $\mathrm{H}_{2}$ Effects: Embrittlement and Reorientation}

UFDC has performed significant recent research into this degradation mechanism as summarized by Stockman et al. (2014). A key finding is that the ductile-to-brittle transition temperature (DBTT) of the cladding is influenced by the cladding temperature history especially during drying. Once the cladding temperature drops below the DBTT, the cladding may breach if subjected to a structural load. Therefore, only if a structural loading event occurs after the cladding temperature has fallen below the DBTT (which may not occur during the 10 -year project period), could gas sampling provide any information on this mechanism.

\subsubsection{Cladding $\mathrm{H}_{2}$ Effects: Delayed Hydride Cracking}

The gap report (Hanson et al. 2012) states:

"DHC [delayed hydride cracking] has traditionally been ruled out as a possible mechanism for cladding degradation during extended storage because as the temperatures decrease, the stress decreases and becomes insufficient to promoter crack propagation (BSC 2004a, EPRI 2002b, Rothman 1984). However, Rothman (1984) noted that additional data are necessary for larger crack depths ( $50 \%$ of wall thickness)....Kim (2009) has proposed a new model for DHC. In this model, creep deformation, prior creep strain, higher burnup, the solvus hysteresis, and the $\gamma$ to $\delta$ hydride phase transition all play important roles in DHC. While there is much disagreement (EPRI 2002b; McRae et al. 2010) with Kim's model (Kim 2009), if Kim's hypotheses are correct, then spent fuel will be more likely to fail by DHC upon cooling below $180^{\circ} \mathrm{C}$ if there are stress raisers inside the rod such as the end cap weld region or incipient cracks due to an interaction of fuel and cladding during reactor operation."

If ${ }^{85} \mathrm{Kr}$ or ${ }^{134} \mathrm{Xe}$ are detected in a gas sample, DHC could be the cause of cladding failure. However, only after the cask is opened and the cladding is examined could this causational relationship be established.

\subsubsection{Oxidation and Corrosion of Cladding}

Oxidation and corrosion of cladding can only occur if there is residual water in the cask after drying or if there is a leak in the cask (which is outside the scope of this report). Water can directly react with the Zircaloy (zirconium alloy) cladding, releasing $\mathrm{H}_{2}$. In addition, radiolysis can break down water into highly 
reactive oxidizing and highly reducing species (including $\mathrm{O}_{2}$ and $\mathrm{H}_{2}$ ). Oxygen can react with the fuel and both oxygen and hydrogen can react with the metals. All of these reactions will most likely occur early in storage until the water is consumed. The water consumption rate is likely to be high because of the elevated temperature and the large metal surface areas relative to the amount of water. Oxidation and corrosion of the cladding is unlikely to result in cladding failure. Therefore, the predictive capability of oxidation related degradation mechanisms of the cladding could not be informed by gas sampling.

\subsubsection{Cladding Creep}

The gap report (Hanson et al. 2012) states:

"The main driving force for cladding creep is the hoop stress caused by internal rod pressure, which will decrease over time as the temperature decreases and the rod volume increases... It is often stated that at temperatures below $300^{\circ} \mathrm{C}$, creep may be considered to be immeasurably slow and is not a factor in extended storage under normal operation (EPRI 2002b). However, there are multiple mechanisms for cladding creep (Murty 2000).... Another potential source of clad strain, regardless of internal pressure, results from the fuel-clad bond. As discussed in Section 5.1.3.2, fuel pellet hourglass swelling and clad creepdown during reactor operations can lead to "bambooing," which may not be visible, but there is more strain at the pellet-pellet interfaces. This strain would be present even at low temperatures... While the strain is obviously much lower than the strain from internal gas pressure, it must be analyzed to see if this strain contributes to creep for some of the low strain mechanisms discussed by Murty (2000)." (Hanson et al. 2012).

If ${ }^{85} \mathrm{Kr}$ or ${ }^{134} \mathrm{Xe}$ are detected while temperatures are high, creep could be the cause of cladding failure. However, only after the cask is opened and the cladding is examined could this causational relationship be established. Long-term low-temperature creep could also cause failure during extended storage, but this would not be seen within the 10 -year project period.

\subsubsection{Summary}

Table 3-1 identifies the mechanisms that could cause the cladding to fail due to within-cask environmental conditions (presence of $\mathrm{H}_{2} \mathrm{O}, \mathrm{O}_{2}$, and $\mathrm{H}_{2}$ ) resulting in release of fission gases and whether any information gained from gas sampling may be useful for informing cladding performance predictive capabilities.

Table 3-1. Cladding Related Degradation Mechanisms that could Influence the in-Cask Gases.

\begin{tabular}{|c|c|c|c|}
\hline Degradation Mechanism & $\begin{array}{c}\text { Could be affected } \\
\text { by presence of } \mathrm{H}_{2} \mathrm{O}, \\
\mathrm{O}_{2}, \text { and } \mathrm{H}_{2} ?\end{array}$ & $\begin{array}{l}\text { Could cause } \\
\text { release of fission } \\
\text { gases from fuel } \\
\text { rods? }\end{array}$ & $\begin{array}{c}\text { Could sampling be } \\
\text { informative for } \\
\text { degradation mechanism? }\end{array}$ \\
\hline Fuel restructuring/swelling & No & Yes & No \\
\hline $\begin{array}{l}\text { Fission product attack on } \\
\text { cladding }\end{array}$ & No & Yes & Yes \\
\hline $\begin{array}{l}\mathrm{H}_{2} \text { effects: embrittlement and } \\
\text { reorientation }\end{array}$ & No & No & No \\
\hline $\begin{array}{l}\mathrm{H}_{2} \text { effects: delayed hydride } \\
\text { cracking (DHC) }\end{array}$ & No & Yes & Yes \\
\hline Oxidation and corrosion & Yes & No & No \\
\hline Creep & No & Yes & Yes \\
\hline
\end{tabular}


The only cladding related information that can be gained from gas sampling is cladding breach. If breach occurs, the cause of a breach may be weakly correlated to a few degradation mechanisms (DHC, fission product attack, and creep). This weak correlation, even if established, may provide only limited data to inform predictive models (which do not currently fully exist) for the degradation mechanisms.

\subsection{All Other Internal SSCs (Assembly Hardware, Baskets and Neutron Poisons)}

Oxidation and corrosion of internal SSCs (assembly hardware, baskets and neutron poisons) can only occur if there is a leak in the cask (which is outside the scope of this report) or if there is residual water (unbound or chemically or physically bound) in the cask after drying. Water can directly react with the metal components in the assembly hardware as well as steels and aluminum in the fuel baskets and neutron poison plates, releasing $\mathrm{H}_{2}$. In addition, radiolysis can break down water into highly reactive oxidizing and highly reducing species including $\mathrm{O}_{2}$ and $\mathrm{H}_{2}$. Oxygen and hydrogen can react with these metals. All of these reactions will most likely occur early in storage until the water is consumed. The water consumption rate is likely to be high because of the elevated temperatures and the large metal surface area relative to the amount of water. While gas sampling can provide the total water consumption rate, it cannot provide the fraction of water, hydrogen, or oxygen consumed by each component or the amount of degradation experienced by each component.

Therefore, any information gained from gas sampling will not be useful for informing performance predictive capabilities for these SSCs.

\section{GAS SAMPLING FREQUENCY STRATEGY}

The main objectives of gas sampling are:

1. Monitoring any residual water and its reactions

2. Determining if and when any cladding breaches

3. Collection of data that may be informative for predictive capabilities.

The gas sampling strategy adopted by the project should be flexible, adaptive, and reflect these objectives. The initial conditions relevant to gas sampling frequency will be established after the cask has been loaded, dried and backfilled with helium while the cask is inside the North Anna decontamination building. An analysis of the gas samples will indicate whether any cladding breached during loading and drying and will provide some indication of whether drying was adequate.

\subsection{Sampling Frequency Strategy for $\mathrm{H}_{2} \mathrm{O}, \mathrm{O}_{2}$, and $\mathrm{H}_{2}$}

An early (within about a year) sample is recommended to be taken after the cask has been moved to the ISFSI pad to confirm the determination of adequate drying $(<0.25$ volume percent water $)$ or to evaluate water concentration if it was above the limit during initial sampling. If water concentration remains at or above the 0.25 volume percent threshold at one year, then the sampling strategy should be revised based on the magnitude of detected gases, which could be indicative of the presence of waterlogged components. If the sample taken at one year indicates that the $\mathrm{H}_{2} \mathrm{O}, \mathrm{O}_{2}$, and $\mathrm{H}_{2}$ concentrations have dropped (or none were detected), then no additional sampling for these gases is warranted within the 10 -year project period.

\subsection{Sampling Frequency Strategy for Fission Gases}

If initial gas sampling indicates the presence of fission gases, then failed rods may have been loaded into the cask or rods may have failed during drying, and the sampling frequency strategy should be revised. If the initial sampling does not indicate the presence of fission gases (i.e., all rods are intact), then the 
frequency of gas sampling would be based on the degradation processes described in Table 3-1. Some processes that could breach cladding are only expected to operate early, due either to the presence of water (oxidation and corrosion) or due to high temperatures (creep, fission product attack and possibly DHC) and may occur during the 10-year project period. Other processes operate later as the temperature drops, such as hydride embrittlement, which could occur as the temperature drops below the DBTT, and are less likely to occur during the 10-year project period.

Because sampling frequency will likely be contingent on the results of the initial conditions established within the first few weeks, and it will also need to be adaptive based on the results of each sampling cycle, the sampling needs and frequencies are presented in the form of an event tree illustrated in Figure 4-1.

\begin{tabular}{|c|c|c|c|c|c|}
\hline $\begin{array}{c}\text { Initial sampling } \\
\text { indicates } \\
\text { presence of } \\
\text { fission gases }\end{array}$ & $\begin{array}{c}\text { Cladding } \\
\text { temperature is } \\
\text { significantly } \\
\text { higher than } \\
\text { expected }\end{array}$ & $\begin{array}{c}\text { Initial sampling } \\
\text { indicates } \\
\text { presence of } \mathrm{H}_{2} \mathrm{O}, \\
\mathrm{H}_{2}, \text { or } \mathrm{O}_{2}\end{array}$ & $\begin{array}{c}\text { Cladding is below } \\
\text { ductile-to brittle } \\
\text { transition } \\
\text { temperature } \\
\text { (DBTT) }\end{array}$ & Recommended Sampling Frequency \\
\hline
\end{tabular}

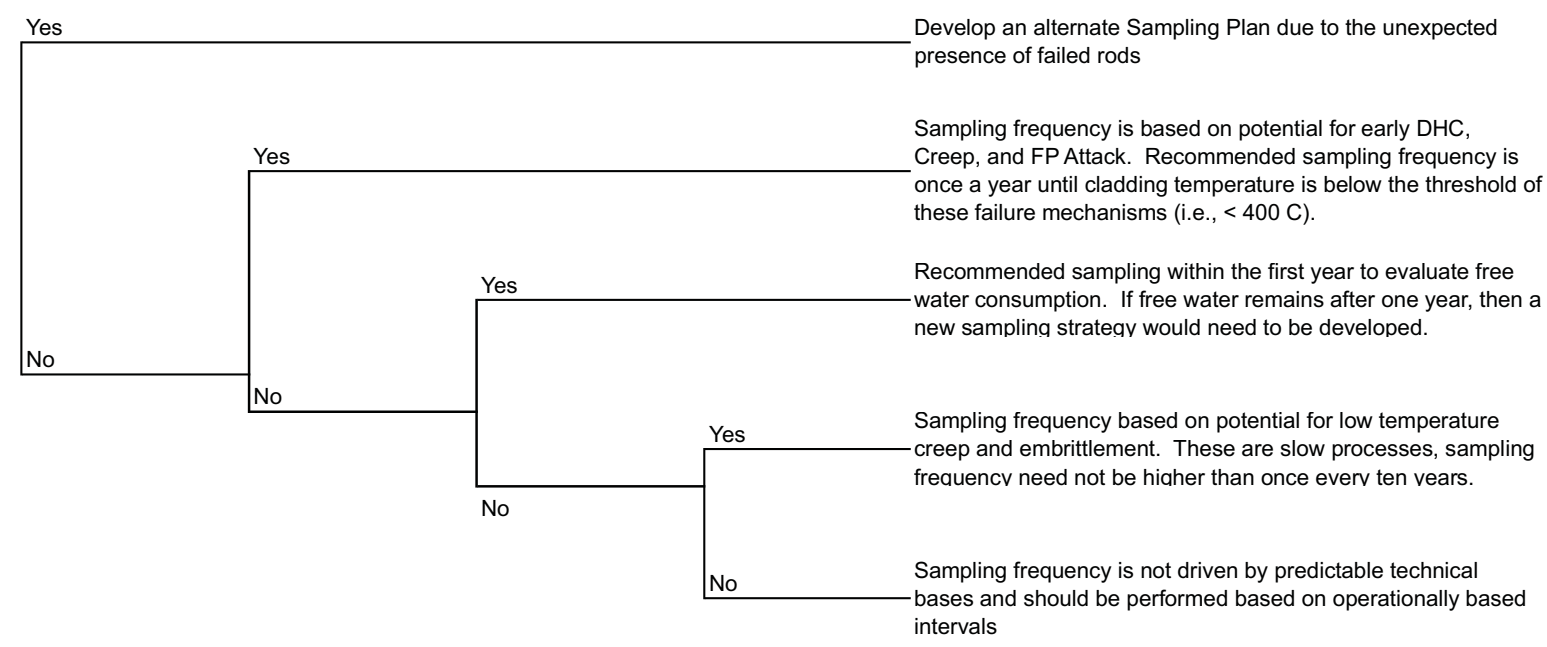

Note: If fission gases are detected during any sampling cycle, a new sampling strategy should be developed due to the presence of failed cladding

Figure 4-1. Sampling Strategy Event Tree.

If an off-normal event such as an earthquake occurs, the sampling strategy should be reevaluated at that time. Finally, a sample should be taken before any planned opening of the cask to help determine whether the cask should be opened or left in storage longer.

\section{CONCLUSIONS}

This report provides a technically based adaptive gas sampling frequency strategy for the HBU Confirmatory Data Project. Gas sampling will provide information on the presence of residual water (and byproducts associated with its reactions and decomposition) and breach of cladding, which could inform the decision of when to open the project cask.

The evaluation of the types and magnitudes of gases that could be present in the project cask concludes that any potential releases of fission gases and residual amounts of water (and associated $\mathrm{O}_{2}$ and $\mathrm{H}_{2}$ ) are well above the minimum detectable concentrations by order of magnitudes. Therefore, potential concentrations of water (as well as $\mathrm{O}_{2}$ and $\mathrm{H}_{2}$ ) and ${ }^{85} \mathrm{Kr}$ and ${ }^{134} \mathrm{Xe}$ (initial and subsequent due to potential cladding failures) will be detectable with standard measurements techniques. 
The potential for gas segregation, which would confound the collection of a representative gas sample, is evaluated. It is concluded that neither gravitational settling nor thermal diffusion would result in any significant gas segregation. Therefore, sampling the gas from the top of the project cask will provide a reasonably representative concentration for ${ }^{85} \mathrm{Kr},{ }^{134} \mathrm{Xe}, \mathrm{H}_{2} \mathrm{O}, \mathrm{O}_{2}$, and $\mathrm{H}_{2}$ throughout the cask.

The degradation mechanisms for the components within the cask are evaluated for any information that could be gained from gas sampling and may be useful for informing component performance predictive capabilities. The degradation mechanisms are evaluated in two groups: those that potentially degrade the unbreached cladding, and those that potentially degrade the other internal components (assembly hardware, basket, and neutron poisons). The results for cladding are shown in Table 3-1. The only cladding related information that can be gained from gas sampling is cladding breach. If breach occurs, the cause of a breach may be weakly correlated to a few degradation mechanisms (DHC, fission product attack, and creep). This weak correlation, even if established, would still not provide any data to inform predictive models (which do not currently fully exist) for the degradation mechanisms. The degradation mechanisms of the other internal components (assembly hardware, basket, and neutron poisons) that could influence gas composition are oxidation and corrosion, which could consume water and its degradation or decomposition products $\mathrm{O}_{2}$ and $\mathrm{H}_{2}$. While gas sampling may provide the total consumption rates of these gases, it cannot provide the fraction of each that is consumed by each component or the amount of degradation experienced by each component. Therefore, any information gained from gas sampling will not be useful for informing performance predictive capabilities for these SSCs.

Because sampling frequency will likely be contingent on the results of the initial conditions established within the first few weeks, an adaptive sampling strategy is developed as illustrated in Figure 4-1. If the early sampling indicates the presence of fission gases, then failed rods may have been loaded into the cask or rods may have failed during drying, and the sampling frequency strategy should be revised. If water is present above the limit ( 0.25 volume percent total oxidizing gases) at one year, then the sampling strategy should be revised based on the magnitude of detected gases, which could be indicative of the presence of waterlogged components. If an off-normal event such as an earthquake occurs, the sampling strategy should be reevaluated at that time.

The operationally based gas sampling strategy calls for sampling the cask four times (shortly after loading, at one year, approximately three years after the one year sampling, and at ten years prior to shipping the cask). The evaluation presented in this report concludes that there are no technical reasons to drive a specific sampling frequency unless an unexpected condition occurs (discovery of failed fuel rods during initial sampling, cladding temperatures above limits, inadequate drying, and off-normal/accident conditions). Not only are these conditions generally not expected, the occurrence of these conditions specifically for the project cask is remote given the loading requirements, inspections, testing, and detailed predictive analyses associated with the HBU Confirmatory Data Project. Therefore, the operationally based sampling frequency is consistent with the technical evaluation presented in this report and reflects the bottom branch of the event tree illustrated in Figure 4-1. 


\section{REFERENCES}

1. Badino G. 2009. The Legend of Carbon Dioxide Heaviness. Journal of Cave and Karst Studies 71, 100-107.

2. BSC. 2007. Characteristics for the Representative Commercial Spent Nuclear Fuel Assembly for Preclosure Normal Operations. 000-PSA-MGR0-00700-000-00A. Bechtel SAIC, Las Vegas, Nevada.

3. BSC. 2004a. Clad Degradation - FEPs Screening Arguments. ANL-WIS-MD-000008, REV 02, Bechtel SAIC Co. LLC, Las Vegas, Nevada.

4. J.T. Carter, R.H. Jones, P.S. Korinko, D. Krementz, T.F. Severynse, W.D. Thompson. 2014. Gas Sampling Alternatives for the High Burn-Up Fuel Cask Research and Development Project. Appendix C-1 in the report by S.C. Marschman, (2014) FCRD-UFD-2014-000475. Prepared for the U.S. Department of Energy Used Fuel Disposition Campaign, Washington, D.C.

5. K. Clusius, G. Dickel. 1938. New Process for Separation of Gas Mixtures and Isotopes. Naturwissenschaften 26, 1.

6. K. Clusius, G. Dickel. 1939. The Separation-Tube Process for Liquids. Naturwissenschaften 27, 148.

7. EPRI. 2014. High Burnup Dry Storage Cask Research and Development Project: Final Test Plan Contract No.: DE-NE-0000593. Electric Power Research Institute, Palo Alto, California.

8. EPRI. 2002a. Dry Cask Storage Characterization Project. TR-1002882, Electric Power Research Institute, Palo Alto, California.

9. EPRI. 2002b. Technical Bases for Extended Dry Storage of Spent Nuclear Fuel. TR-1003416, Electric Power Research Institute, Palo Alto, California.

10. C. Ferry, C. Poinssot, V. Broudic, C. Cappelaere, L. Desgranges, P. Garcia, C. Jegou, P. Lovera, P. Marimbeau, J.-P. Piron, A. Poulesquen, D. Roudil, J.-M. Gras, and P. Bouffioux. 2005. Synthesis on the Spent Fuel Long Term Evolution. CEA-R-6084, Commissariat À L'Énergie Atomique, Paris, France.

11. K.E. Grew, T.L. Ibbs. 1952. Thermal diffusion in gases: University Press.

12. B. Hanson, H. Alsaed, C. Stockman, D. Enos, R. Meyer, and K. Sorenson. 2012. Gap Analysis to Support Extended Storage of Used Nuclear Fuel. FCRD-USED-2011-000136 Rev. 0, PNNL-20509, Prepared for the U.S. Department of Energy Used Fuel Disposition Campaign, Washington, D.C.

13. Y.S. Kim. 2009. Hydride Reorientation and Delayed Hydride Cracking of Spent Fuel Rods in Dry Storage. Metallurgical and Materials Transactions A, 40A:2867-2875.

14. R.W. Knoll, E.R. Gilbert. 1987. Evaluation of Cover Gas Impurities and Their Effects on the Dry Storage of LWR Spent Fuel. PNL-6365, DE88 003983, Prepared for the U.S. Department of Energy under Contract DE-AC06-76RL0 1830. Washington, D.C.

15. R. Kohli, D. Stahl, V. Pasupathi, A.B. Johnson Jr., and E.R. Gilbert. 1985. The Behavior of Breached Boiling Water Reactor Fuel Rods on Long-Term Exposure to Air and Argon at 598 K. Nuclear Technology 69:186.

16. S.C. Marschman. 2014. Instrumentation Workshop with Industry. FCRD-UFD-2014-000475. Prepared for the U.S. Department of Energy Used Fuel Disposition Campaign, Washington, D.C.

17. G.A. McRae, C.E. Coleman, B.W. Leitch. 2010. The First Step for Delayed Hydride Cracking in Zirconium Alloys. Journal of Nuclear Materials 396(2010): 130-143. 
18. K.L. Murty. 2000. The Internal Pressurization Creep of Zr Alloys for Spent-Fuel Dry Storage Feasibility. Journal of the Minerals, Metals and Materials Society (JOM) 52:9 (2000) 34.

19. NRC. 2012. Identification and Prioritization of the Technical Information Needs Affecting Potential Regulation of Extended Storage and Transportation of Spent Nuclear Fuel. Draft for comment. ML12130A189. U.S. Nuclear Regulatory Commission, Washington, D.C.

20. NRC. 2010. Standard Review Plan for Spent Fuel Dry Storage Systems at a General License Facility. NUREG-1536, Rev 1, U.S. Nuclear Regulatory Commission, Washington, D.C.

21. A.J. Rothman. 1984. Potential Corrosion and Degradation Mechanisms of Zircaloy ${ }^{\mathrm{TM}}$ Cladding on Spent Nuclear Fuel in a Tuff Repository. Report Attachment 10 to MRB-0418, JUCID-20172, Lawrence Livermore National Laboratory, Livermore, California.

22. Stockman, BD Hanson, SC Marschman, HA Alsaed, KB Sorenson. 2014. Used Nuclear Fuel Extended Storage and Transportation Research and Development Review and Plan. FCRD-UFD-2014-000050. SAND2014-19594 R. Prepared for the US Department of Energy Used Fuel Disposition Campaign, Washington, D.C.

23. J.C. Theilacker, M. White. 2005. Diffusion of Gases in Air and Its Affect on Oxygen Deficiency Hazard Abatement. FERMILAB-CONF-05-635-AD. Presented at Fermilab Conference 2005.

24. UFDC. 2012. Review of Used Nuclear Fuel Storage and Transportation Technical Gap Analyses, FCRD-USED-2012-000215, PNNL-21596, Prepared for the US Department of Energy Used Fuel Disposition Campaign, Washington, D.C. 


\section{APPENDIX A: \\ Possible Segregation of Gases in the Project Cask}


Evaluation of the Frequency for Gas Sampling for the High Burnup Confirmation Data Project May 22, 2015 FCRD-UFD-2015-00051, INL/EXT-15-35368

This page intentionally left blank. 


\section{Appendix A: Possible Segregation of Gases in the Project Cask}

\section{A-1. Background}

The gas samples will be drawn from a vent at the top of the cask. One concern is that the krypton which is much heavier than the He backfill gas, could accumulate at the bottom of the cask; thus rendering sampling from the top of the cask ineffective for detection of $\mathrm{Kr}$.

A schematic of the TN-32 cask is shown in Figure A-1. The cask contains 32 pressurized water reactor (PWR) assemblies, in a stainless steel basket. Each cell of the basket extends the length of the canister, with a gap of 1-2 inches between the top of the basket and the inside of the lid. The basket rests directly on the bottom of the cask, but at the bottom of each cell wall is an arcuate cutout, a 0.4 " high segment of a circle with a radius of 3" (not shown in Figure A-1), to allow drainage from the basket during drying operations. The spaces between the basket and the inner wall of the cask contain hollow alignment rails or spacers (not shown in Figure A-1), which are open at the top, but do not have cutouts at the bottom. The hollow rails do drain, however, through gaps between the plates, which are bolted together, and through bolt-holes (W. Bracey, personal communication). Two ports, used to drain the canister and fill it with $\mathrm{He}$ during drying, are located at the top of the cask. One port has a siphon that extends to the floor of the cask, for draining the cask. However, as currently designed, this port cannot be used for gas sampling, and redesigning the port would require a license amendment. The second port provides access to the headspace at the top of the cask; it is through this port that gas samples will be taken.

Modelling at the Pacific Northwest National Laboratory (PNNL) (H. Adkins, personal communication.) indicates that the gases within the project cask will be convecting, moving up through the central cells of the basket, and down through the outer cells; global circulation involving movement through the hollow rails is not possible, because the rails do not have cutouts at the bottom.

In order for gas segregation to impact detection of ${ }^{85} \mathrm{Kr}$, a vertical compositional gradient would have to be present within the cask, such that the any $\mathrm{Kr}$ would accumulate at the bottom of the cask, and be depleted at the top of the cask. This is shown schematically in Figure A-2. Here, processes that could lead to gas separation within the cask are discussed.

Possible mechanisms that could lead to compositional gradients within a cask include:

1. Gravitational settling of the heavier, denser $\mathrm{Kr}$ within a stagnant cask. This could conceivably occur immediately after breach of a fuel rod, but a stable compositional gradient cannot be maintained over time, even in a static gas column. Within a convecting gas column, the effects of gravitational settling would be even more rapidly eliminated.

2. Thermal diffusion. Thermal diffusion could result in minor degrees of compositional variation in the gas phase within a stagnant cask, but sufficient separation to affect ${ }^{85} \mathrm{Kr}$ detection is not possible. Conversely, and perhaps counter-intuitively, in a convecting system, the combined effects of thermal diffusion and convection may lead to high degrees of separation, if the appropriate geometry exists. This does not appear to be the case for the high burnup project cask. 

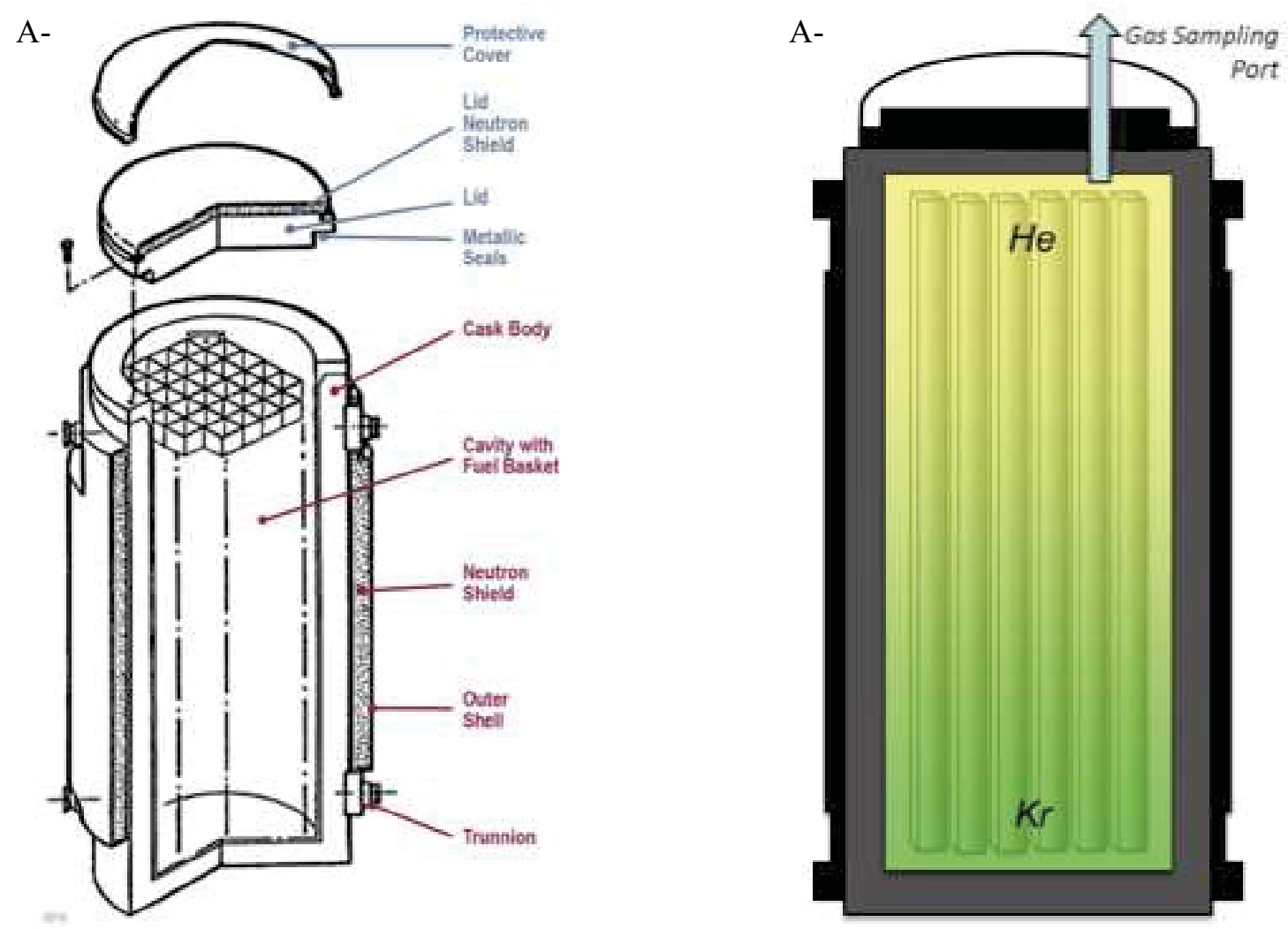

Figure A-1. Schematic of the TN-32 storage cask to be used in the project.

Figure A-2. Compositional gradient required in the project cask for $\mathrm{Kr}$ detection by headspace gas sampling to be ineffective.

\section{A-2. Gravitational Effects}

Based on computational fluid dynamics (CFD) modeling of heat loss from the fuel in the cask (H. Adkins, personal communication), the gas phase in the cask will slowly convect. Therefore, gas stagnation within the cask is not anticipated to occur. In a convecting system, the very minor effects of buoyancy are eliminated, and development of a stable density gradient in the cask through gravitational processes is impossible. However, only limited convection is predicted-most heat loss is conductive. If it is assumed that a static system can actually occur, could a density-driven compositional gradient exist stably in the cask?

Consider two different initial conditions:

- The initial gas phase is well-mixed

- $\mathrm{Kr}$ is released from a rod as a discrete density flow and moves to the bottom of the cask-will it persist stably at the cask floor, or will the Kr mix into the gas column?

In the initially mixed $\mathrm{He}-\mathrm{Kr}$ gas system, will $\mathrm{Kr}$ separate out and settle to the bottom of the canister because of the higher density of the gas? In an isothermal, adiabatic system, clearly not - this would violate the laws of thermodynamics, resulting in a decrease in system entropy. At a fixed temperature, diffusion of different gas components will be down a compositional gradient, from high to low concentration, which results in greater mixing, not less. Atom-atom collisions ("Brownian motion") tend to disperse the atoms and to mix them, regardless of mass. The buoyancy effect is negligible (Badino, 2009). 
In a thermal gradient, the competing process of thermal diffusion can work against this, but can only have a minor effect in a static system, as will be discussed later.

However, gas stratification can and does exist. For a mixed gas system, if there is a sufficiently tall gas column, then the weight of the overlying gas column compresses the gases at the bottom of the column, and the difference in density of the different gas components results in compositional variation along the height of the column. This effect is generally very small and is eliminated by any advective flow. It occurs in the earth's atmosphere at very high altitudes $(>100 \mathrm{~km})$, where winds do not mix the atmosphere. As one goes into space, the thin upper atmosphere is sequentially enriched in molecular nitrogen, atomic oxygen, helium, and finally, hydrogen (Badino, 2009). This effect is readily calculated if we assume ideal gas behavior and isothermal conditions. For a pure gas, under isothermal conditions, the gas pressure as a function of altitude is given by (Eq. 3 in Badino, 2009):

$$
P=P_{0} \exp \left(-\frac{M_{m o l} g}{R T_{0}} Z\right)
$$

where:

$z$ is the altitude in $\mathrm{km}$

$P$ is the pressure at the altitude of interest

$P_{0}$ is the pressure at an elevation of $z=0$

$M_{m o l}$ is the molar mass in $\mathrm{kg} \mathrm{m}^{-3}$

$\mathrm{g}$ is the gravitational constant

$\mathrm{R}$ is the gas constant, $8.3142 \mathrm{~J}_{\text {mole }}{ }^{-1} \mathrm{~K}^{-1}$

$\mathrm{T}_{0}$ is the temperature in $\mathrm{K}$ at an elevation of $z=0$

It is apparent from Eq. 1 that the change in gas pressure with altitude is a function of the molecular mass. If ideal gas behavior and isothermal conditions are assumed, then although the gas in the project cask is mixed, the component phases can be treated independently, and the change in partial pressure of each gas with altitude behaves as if the other gas did not exist. Using Eq. 1, the ratio of $\mathrm{Kr}$ impoverishment, as a function of elevation is given by (Eq. A3 in Badino, 2009):

$$
\frac{P_{K r}}{P_{H e}}=\exp \left(\frac{z g M_{m o l-K r}}{R T_{0}}-\frac{z g M_{m o l-H e}}{R T_{0}}\right)
$$

In a 5-meter tall cask, this effect is negligible, even with two such dissimilar gases as $\mathrm{He}$ and $\mathrm{Kr}$. Assuming a concentration of $\mathrm{Kr}$ of $5 \%$ in the bottom of the cask, at $25^{\circ} \mathrm{C}$, the concentration of $\mathrm{Kr}$ at the top of the cask ( $\sim 5$ meters higher) would be $4.992 \%$. At $200^{\circ} \mathrm{C}$, the degree of depletion is less; the $\mathrm{Kr}$ concentration at the top of the cask would be $4.995 \%$.

The opposite case can also be considered. If $\mathrm{Kr}$ is released as a stream from a failed fuel rod, it can settle to the bottom of the cask as a density flow, mixing little with the He fill gas. Such gravitational settling is a well-known phenomenon. In an isothermal system, the two gases would eventually mix, creating the same negligible compositional gradient that would develop from the well-mixed system, as described in Eq. 2 above. This must happen, because the equilibrium condition must be the same, regardless of the direction of approach to equilibrium.

The rate of diffusive mixing in two-gas systems has been experimentally measured by Theilacker and White (2005). In one system, they injected He into the top of a static air column open at the bottom, and measured the time required for the He to completely diffuse out of the column; this took approximately 20 hours. In a second system, they injected sulfur hexafluoride into the bottom of the column, and allowed it to diffuse out the top. The rate of diffusive gas loss was a function of the gas molecular mass, but Theilacker and White were able to match the experimental data exactly using a simple binary diffusion 
equation, with diffusivities calculated from the molecular masses of the gases, and treating air as a single molecular species with a formula weight of $29 \mathrm{~g} / \mathrm{mol}$. In the case of sulfur hexafluoride, which has a formula weight $146 \mathrm{~g} / \mathrm{mole}$, the gas took about 5 days to diffuse completely out the top of a $150 \mathrm{~cm}$ air column at ambient temperatures.

The results for a $150 \mathrm{~cm}$, ambient temperature $\mathrm{He}-\mathrm{Kr}$ system would fall between these results, as He atoms are lighter than the average molecule in air and would diffuse more rapidly (the diffusion rate of a gas molecule is proportional to the mass), and $\mathrm{Kr}$ atoms are heavier than molecules in air and would diffuse more slowly, but are lighter than $\mathrm{SF}_{6}$. Although the project cask is 5 meters high, given that diffusion is more rapid at elevated temperatures, it is reasonable to assume that equilibration within the cask would occur within days or weeks at most.

This assumes that the cask is a static, isothermal system. Is it possible that the cask could be a static system with a temperature gradient, such that cooler, denser gases in the bottom of the cask would further serve to stabilize a compositional gradient? No. First, as noted above, buoyancy has little effect on the diffusive mixing of gases. Second, the thermal source within the cask is the fuel assemblies, which can roughly be considered to be a rectangular or cylindrical vertical source along the axis of the cask. As heat loss is dominantly from the top and sides of the cask, and not from the bottom, which rests on the concrete pad, any temperature gradient that could develop in the cask would be cooler at the sides or the top, not at the bottom of the cask. It is expected that the pattern of heat loss would result in density-driven convection in the cask, and that is what CFD modeling of the project cask suggests will happen.

\section{A-3. Thermal Diffusion}

While it would seem that convection would mix two gases within a closed system, this is not necessarily true. Thermal diffusion (also known as Soret diffusion), or the development of a compositional gradient in response to a thermal gradient, can, in a convecting system, result in high degrees of compositional segregation.

The potential for the development of compositional gradients in response to thermal gradients in gas systems was first recognized in the early 1900s, and was extensively studied experimentally in the period from 1920-1950. The seminal book on thermal diffusion is Grew and Ibbs (1952); the following discussion draws heavily on that book.

To understand thermal diffusion, it is useful to first consider a static system.

\section{A-3.1 Static System}

In a two-component static gas system with a temperature gradient, thermal diffusion will result in the development of a small compositional gradient within the system. The lighter component will be slightly concentrated towards the hotter end, while the heavier component will be slightly concentrated towards the cooler end. The separation of gases by thermal diffusion in static systems has been measured using a simple experimental design (Figure A-3), consisting of two bulbs one heated, and the other cooled. The bulbs are connected by a narrow tube, and the system is filled with a homogenously mixed gas. The narrow connecting tube allows diffusion, but not advective mixing. After allowing the system to equilibrate for a sufficient time, the gas within each bulb is sampled and analyzed. By varying the temperature of each bulb, the effect of thermal diffusion as a function of the temperature difference (and of the absolute temperatures) can be quantified. 
The general equation for the degree of separation as a function of temperature is given by (Grew and Ibbs, 1952):

$$
n_{10}^{\prime}-n_{10}^{\prime \prime}=k_{T} \ln \left(T^{\prime} / T\right)
$$

where:

$n^{\prime}{ }_{10}$ is the conc. of component 1 at temperature $T$

$n^{\prime \prime}{ }_{10}$ is the conc. of component 1 at temperature $T^{\prime}$

$\left(n_{10}^{\prime}-n_{10}^{\prime \prime}\right)$ is termed the separation

$k_{T}$ is the thermal diffusion ratio

$T$ is the temperature at one end of the system

$T^{\prime}$ is the temperature at the other end of the system

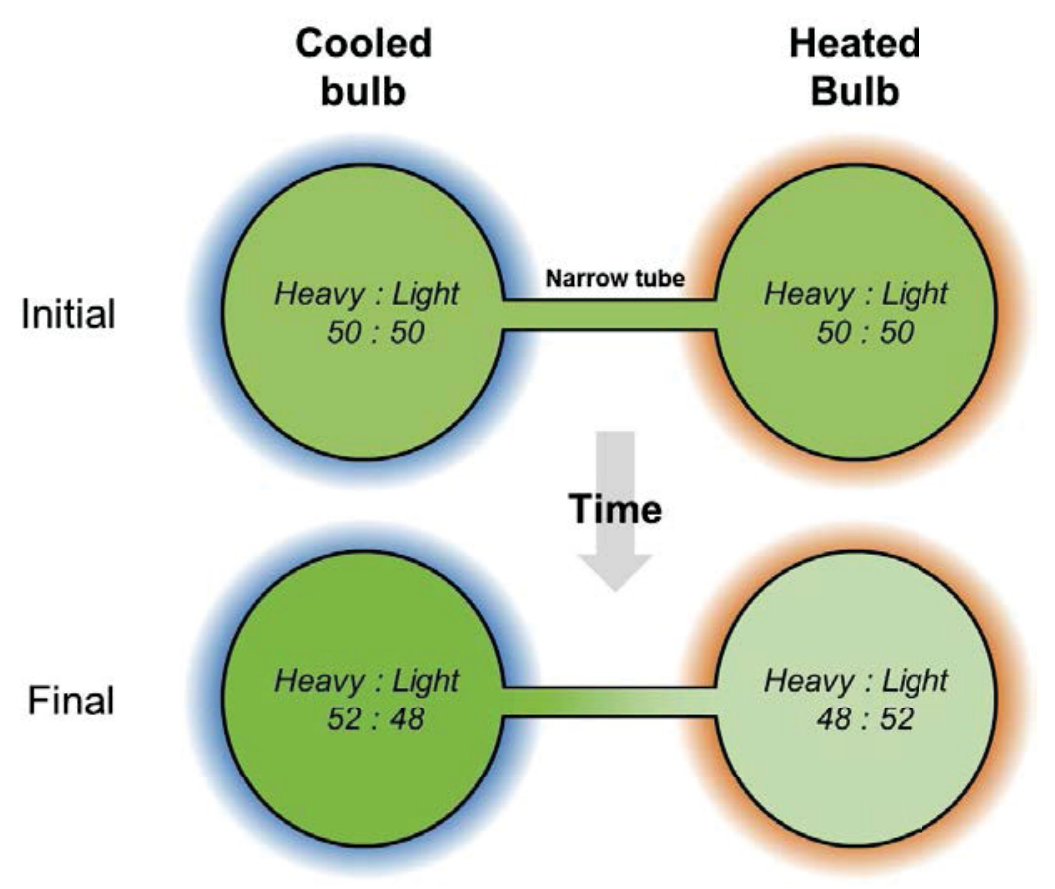

Figure A-3. Schematic of experimental setup used to measure gas separation by thermal diffusion.

The thermal diffusion coefficient, $k_{T}$, is equal to (Grew and Ibbs, 1952):

$$
k_{T}=\left(I-\frac{a}{2}\right) \frac{a_{1} n_{10}-a_{2} n_{20}}{b_{1} n_{10}^{2}+b_{2} n_{20}^{2}+b_{12} n_{10} n_{20}} n_{10} n_{20}
$$

where:

$n_{10}$ and $n_{20}$ are the bulk concentrations of components 1 and 2, respectively, in the system.

$\left(I-\frac{a}{2}\right)$ describes the extent to which the gas atoms/molecules behave as rigid elastic spheres.

$a_{1}, a_{2}, b_{1}, b_{2}$, and $b_{12}$ are functions of the molecular diameters and masses of the gas species; the functional relationships are given in Appendix 1 of Grew and Ibbs (1952).

From Eq. 3, it is clear that that the separation $\left(n^{\prime}{ }_{10}-n^{\prime \prime}{ }_{10}\right)$ is a function of the temperature difference between the two ends of the system, in the form of $\ln \left(T^{\prime} / T\right)$. 
Examples of the temperature dependence of the separation are given in Figure A-4 and Figure A-5. In Figure A-4, the dependence of separation on $\log \left(T^{\prime} / T\right)$ is illustrated for a $\mathrm{H}_{2}: \mathrm{N}_{2}$ mixture (atomic mass ratio about 2:28) containing $39.8 \mathrm{~mol}^{\circ} \mathrm{H}_{2}$ (Grew and Ibbs, 1952; modified from Figure 5). The temperature at one end of the experimental setup (Figure A-3) was held at an ambient temperature of $293 \mathrm{~K}\left(20^{\circ} \mathrm{C}\right)$, while the temperature at the other end was varied from $<90 \mathrm{~K}\left(-183^{\circ} \mathrm{C}\right)$ to $600 \mathrm{~K}\left(327^{\circ} \mathrm{C}\right)$. Despite the large mass difference (a factor of 14 ), a temperature difference of over $500 \mathrm{~K}$ only resulted in about $12 \%$ separation, or difference in composition, between the hot and cold ends of the system. For a temperature difference of $293 \mathrm{~K}\left(20^{\circ} \mathrm{C}\right)$ to $600 \mathrm{~K}\left(327^{\circ} \mathrm{C}\right)$, the separation was $6 \%$. This is a much larger temperature difference than is expected to occur anywhere in the project cask.

A-4.

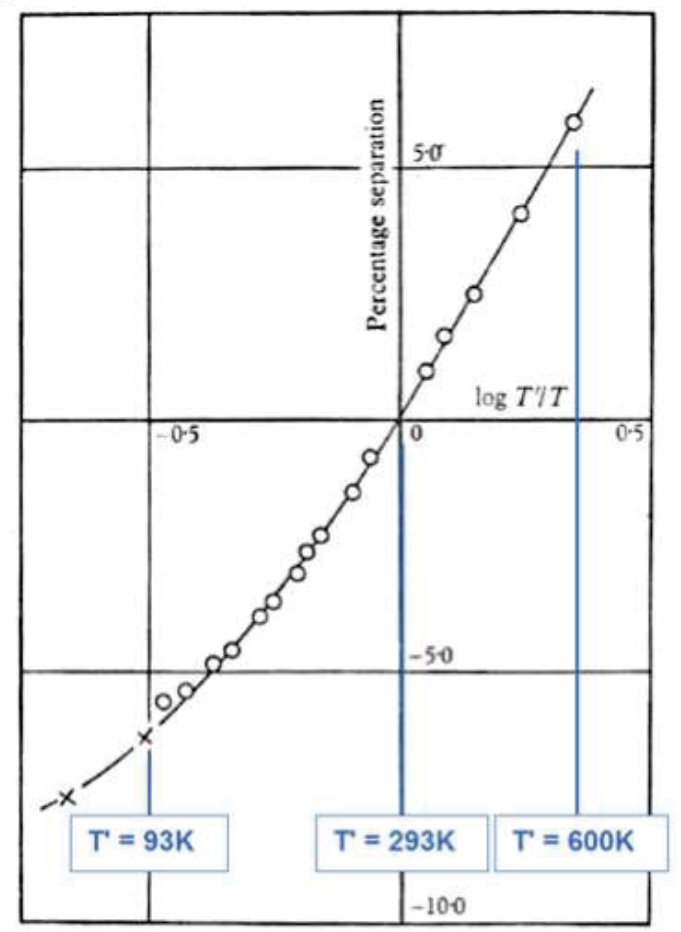

A-5.

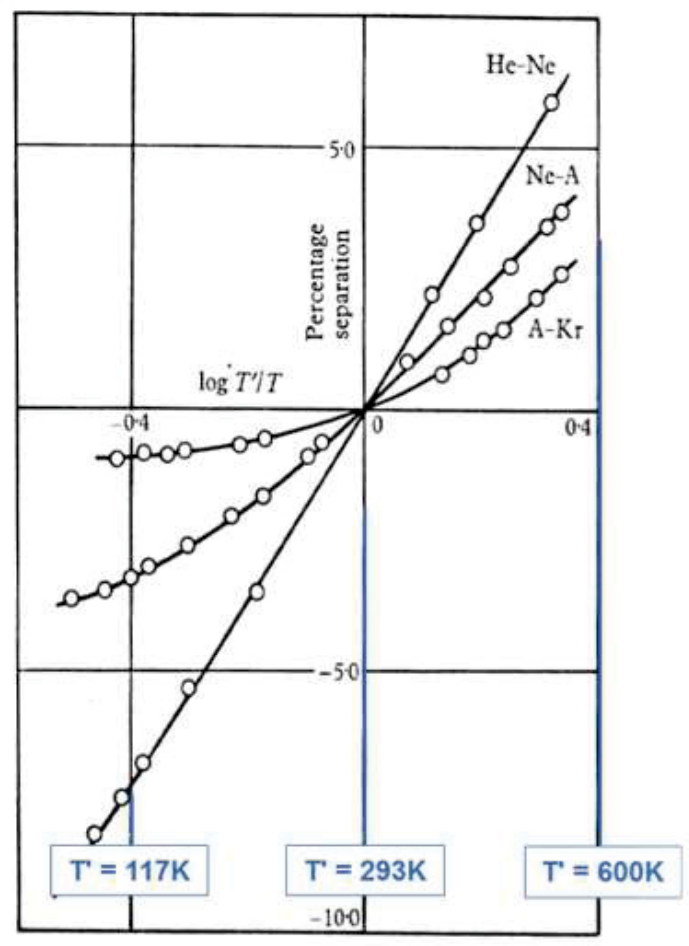

Figure A-4. Degree of separation as a function of temperature difference, for a $\mathrm{H}_{2}-\mathrm{N}_{2}$ mixture containing $39.8 \mathrm{~mol}_{0} \mathrm{H}_{2}$.

Figure A-5. Degree of separation as a function of temperature difference, for mixtures of (1) He-Ne $(53.8 \% \mathrm{He}) ;(2) \mathrm{Ne}-\mathrm{Ar}(51.2 \% \mathrm{Ne})$, and (3) $\mathrm{Ar}-\mathrm{Kr}(53.5 \% \mathrm{Ar})$.

Additional examples are given in Figure A-5 (Grew and Ibbs, 1952; modified from Figure 17). The dependence of separation on $\log \left(T^{\prime} / T\right)$ is illustrated for mixtures of: (1) He:Ne (atomic mass ratio about 4:20), containing $53.8 \mathrm{~mol} \% \mathrm{He}$; (2) Ne:Ar (atomic mass ratio about 20:40), containing $51.2 \% \mathrm{Ne}$; and (3) $\mathrm{Ar}-\mathrm{Kr}$ (atomic mass ratio of 40:84), containing 53.5\% Ar. In each case, temperature differences of about $250^{\circ} \mathrm{C}$, from ambient temperature to the highest tested, resulted in only a small separation (a maximum of about $6 \%$ ).

An important feature in Figure A-5 is the relationship between the mass difference of the two gas components and the degree of separation. The mass and size differences affect the degree of separation through the thermal diffusion coefficient $k_{T}$ (Eq. 4). The $a$ and $b$ variables in Eq. $4\left(a_{1}, a_{2}, b_{1}, b_{2}\right.$, and $\left.b_{12}\right)$ 
are functions of the molecular diameters and masses of the gas species. If we assume that gas atoms can be treated as rigid elastic spheres, then the effect of these variables is that, in a system with two gas components, separation is greater as the difference in mass and atom/molecule diameters increases. This is exactly what is observed in the experimental systems shown in Figure A-5, which have approximately equal amounts of each gas component present. On the basis of this, it can be inferred that in a static system with approximately equal amounts of $\mathrm{He}$ and $\mathrm{Kr}$ (mass difference 4:85), greater separation would be seen than the maximum shown in Figure A-5. However, the amount of separation does not vary linearly with the mass difference, because with increasing mass, the noble gases become softer, behaving less like rigid elastic spheres. This is incorporated into $k_{T}$ (Eq.4) through the term $\left(I-{ }^{a} / 2\right)$. Measured values for the deviation from ideal gas behavior for noble gas mixtures are provided in Grew and Ibbs (1952; Table I). For a mixture of $\mathrm{He}$ and $\mathrm{Ne}$, the separation is $80 \%$ of the predicted ideal behavior; for $\mathrm{He}$ and $\mathrm{Kr}$, it is $63 \%$ of ideal behavior. Although rare, for large, flexible molecules that have complex interactions with a second gas component of only slightly different mass, the effect of non-ideal behavior can actually result in reverse separation - that is, the heavier molecule actually segregates towards the hotter end of the system (Grew and Ibbs, 1952).

An additional important parameter for calculating the thermal diffusion coefficient is the final term in Eq. $4, n_{10} n_{20}$, or the product of the bulk concentration of component 1 and the bulk concentration of component 2. This term is very important, because it shows that the degree of separation is a function of the composition of the mixed gas - the relative proportion of component 1 and component 2 . The value of $n_{10} n_{20}$ is potted against $n_{10}$ in Figure A-6. It is maximum when $\mathrm{n}_{10}=\mathrm{n}_{20}=0.5$, and decreases as the concentration of either gas becomes smaller. This indicates that the degree of separation should show a similar trend, and be highest when the proportions of each gas are equal, or nearly so. Measured data show that this is true. Figure A-7 (Grew and Ibbs, 1952; Figure 15) shows the degree of separation for mixtures of $\mathrm{Kr}: \mathrm{He}$ (atomic mass ratio 4:84), $\mathrm{Kr}: \mathrm{Ne}$ (atomic mass ratio 20:84) and $\mathrm{Kr}$ :Ar (atomic mass ratio 40:84) with $\mathrm{T}=288 \mathrm{~K}$ and $\mathrm{T}^{\prime}=373 \mathrm{~K}$. In each case, separation is low when the proportion of either gas species becomes small, and is highest when the proportions are near-equal. The peak is not exactly when the gases are of equal proportion (the term $n_{10} n_{20}$ also occurs in the denominator of the middle term in Eq. 4 ), but is close.

A-6.

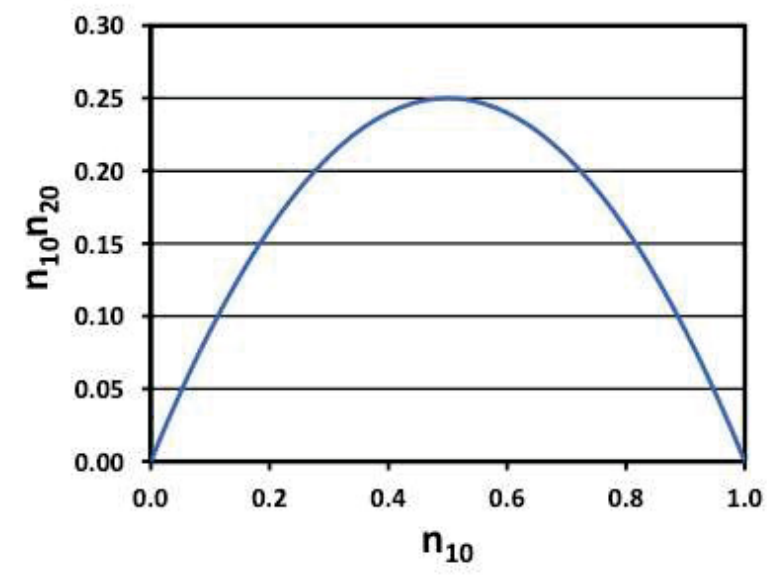

A-7.

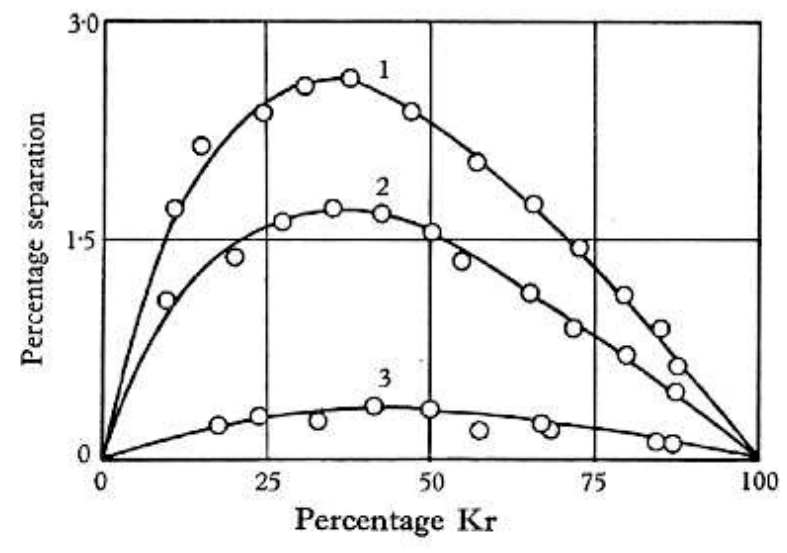

Figure A-6. Plot of $n_{10} n_{20}$ vs. $n_{10}$.

Figure A-7. Degree of separation as a function of gas phase composition, for mixtures of (1) Kr-He, (2) $\mathrm{Kr}-\mathrm{Ne}$, and (3) Kr-Ar. T = 288K; T' $=373 \mathrm{~K}$. 
In the project cask, the mole fraction of $\mathrm{Kr}$ in the cask will be very small. Hence, if we assume the cask is a static system with any reasonable temperature differential, the amount of separation, despite the large mass difference, would be negligible. An additional point from Figure A-7 is that the degree of separation for the He:Kr system, mass ratio of 21 , is only slightly higher than that for $\mathrm{Ne}: \mathrm{Kr}$, mass ratio of $\sim 4$. As noted previously, the degree of separation of two gases does not scale linearly with the mass ratio, in part because the larger noble gases are "softer" (behave less like rigid spheres) than the smaller ones.

It is evident that if the cask is treated as a static system, it is not possible to achieve significant separation by thermal diffusion effects. Assuming reasonable temperature variations in the cask, if equal amounts of $\mathrm{He}$ and $\mathrm{Kr}$ are assumed to be present, separation could only be in the several percent range. In actuality, the expected concentrations of $\mathrm{Kr}$ are very low, and separation would be negligible.

\section{A-3.2 Convecting System}

As noted previously, CFD modeling indicates that convection will be occurring in the cask. It will not be a static system. While it might seem that convection would only serve to mix gases within the cask, eliminating any possible compositional gradient, this is not necessarily true. In some systems, a combination of convection and thermal diffusion can result in very high degrees of gas separation. The classic example of this is the Clusius-Dickel column (Clusius and Dickel, 1938; 1939). The Clusius Dickel column is shown schematically in Figure A-8. It consists of a cylindrical tube with a cooling jacket on the exterior, and a heated central wire. In response to the heating, a convection cell develops within the column, with the gas rising near the wire and cooling and falling around the perimeter of the column. Over time, a vertical compositional gradient develops in the column, which can result in much larger degrees of separation than can occur in a static system. Using a column 1 meter in length and 1 centimeter in diameter, and a central wire heated to about $500^{\circ} \mathrm{C}$, Clusius and Dickel (Clusius and Dickel, 1938) were able to achieve almost complete separation of $\mathrm{H}_{2}$ and $\mathrm{CO}_{2}$. Using several linked columns to achieve an aggregate length of 36 meters, they were able to achieve nearly complete separation of ${ }^{35} \mathrm{Cl}$ and ${ }^{37} \mathrm{Cl}$. This illustrates that under ideal conditions, gases with even small mass differences can be separated by thermal diffusion.

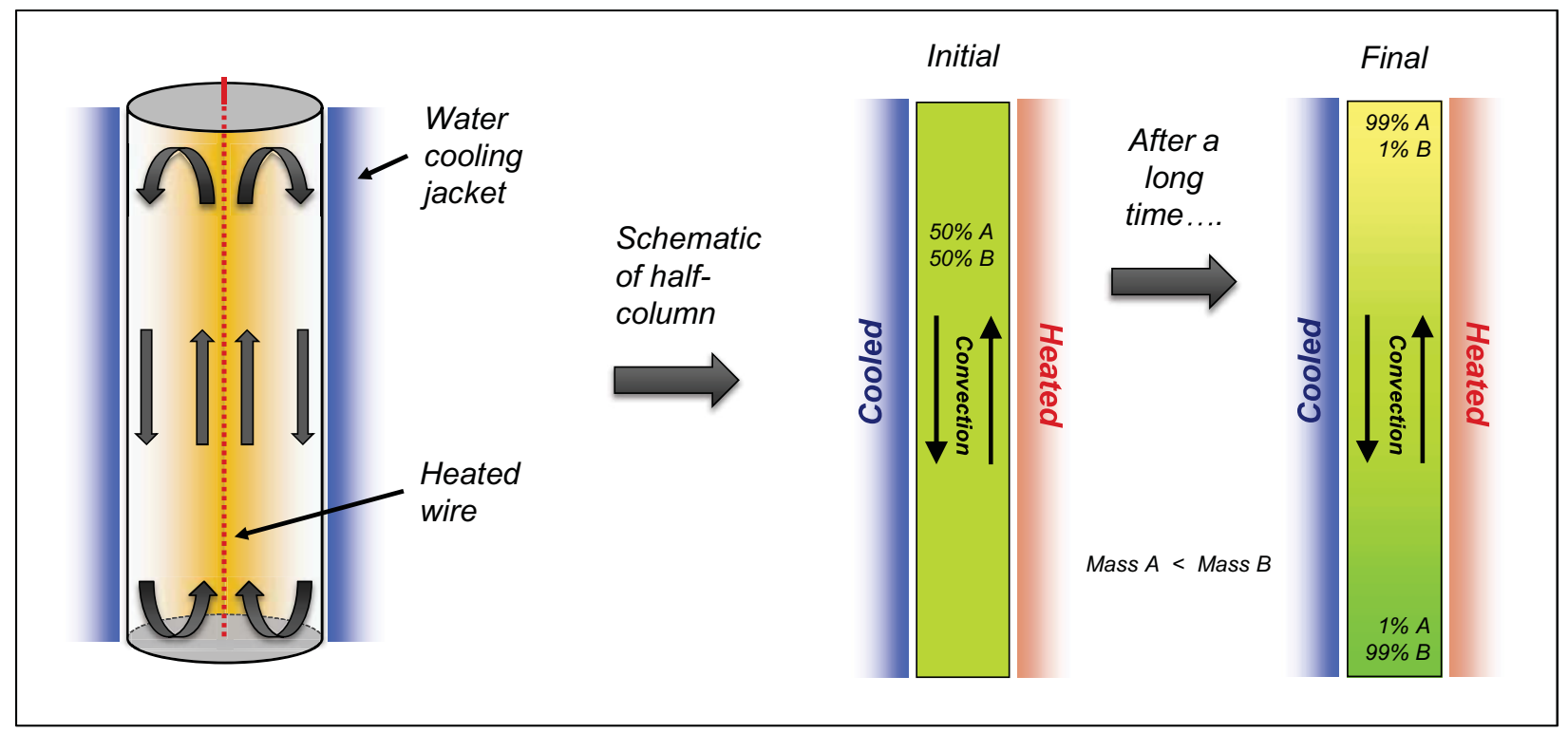

Figure A-8. Schematic illustration of a Clusius-Dickel column.

The enhanced separation in a Clusius-Dickel column occurs by the combined effects of convection and thermal diffusion. Although these processes occur simultaneously, the mechanism of enrichment is best illustrated by separating the effects of these two processes as shown in Figure A-9. In the figure, a 
half-section of a Clusius-Dickel column is discretized into 8 levels, each consisting an inner (hot) cell and an outer (cool) cell. The numbers in each cell are the percent fraction of the heavy gas species in each cell. In the initial state, the gases are homogeneously distributed in the column (50\% in each cell). In the first step, thermal diffusion creates a compositional gradient between the heated side (the hot wire) and the cooled wall. In this example, the separation is assumed to be $4 \%$. In the second step, the gas phase convects one cell. Now the top of the column, two cells enriched in the light species are juxtaposed, while at the bottom, two cells enriched in the heavy phase are placed adjacent to each other. In the subsequent diffusion step, the separation between adjacent cells again becomes $4 \%$, but an overall compositional gradient has been established between the top and the bottom of the column. In succeeding alternating convection and diffusion steps, the top cells become more enriched in the light phase, and the bottom cells, more enriched in the heavy phase. In this example system, a steady state separation is eventually achieved with the heavy phase present at a maximum concentration of $66 \%$ at the bottom, and $34 \%$ at the top. But this separation is a function of the vertical discretization of the column. In a column that is discretized on a finer scale, the separation would be greater, and in an infinitely finely discretized column, the gradient would be complete, from pure light phase at the top to pure heavy phase at the bottom.

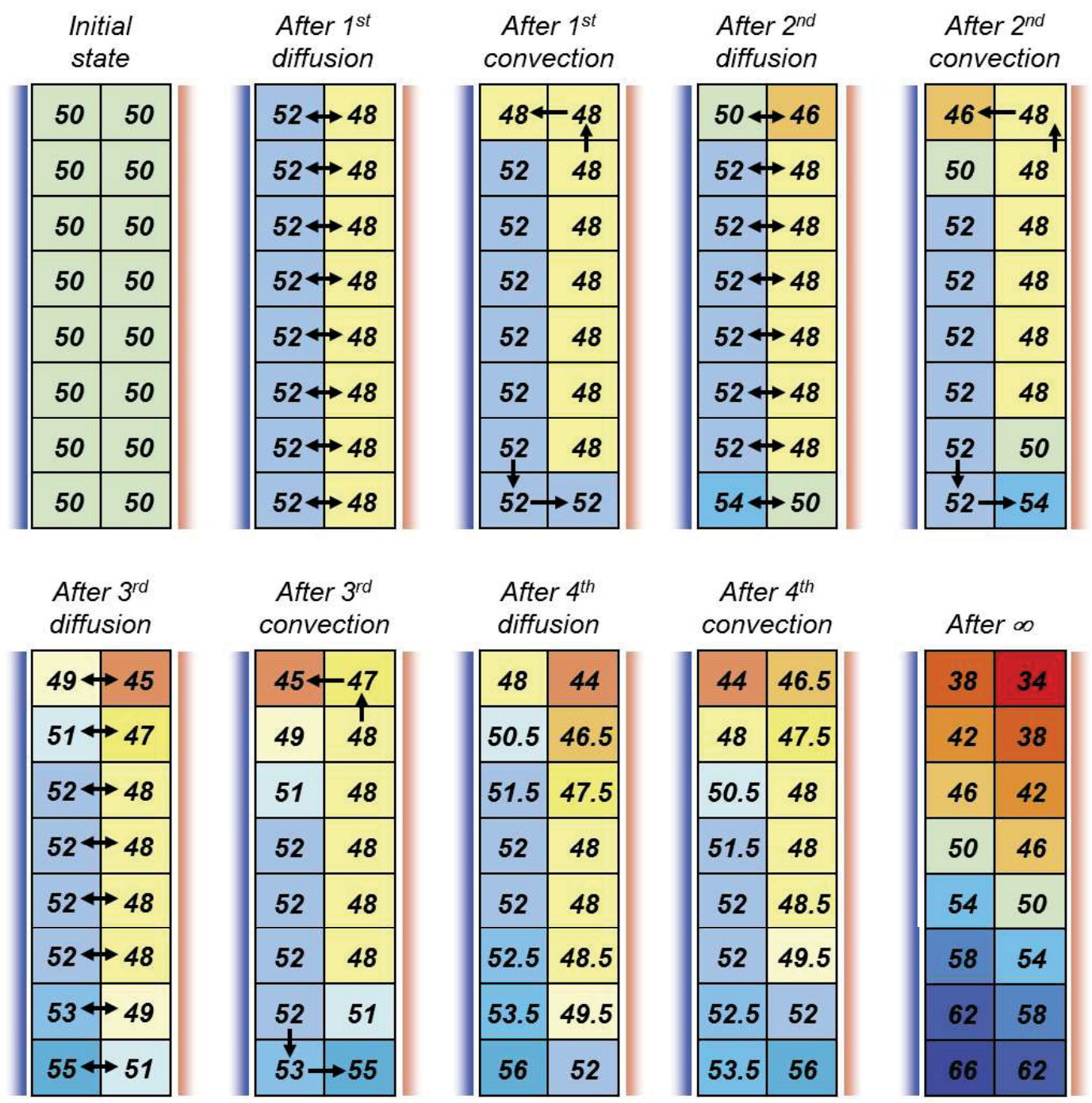

Figure A-9. Schematic illustrating the compositional separation in a Clusius-Dickel column by the combined effects of diffusion and convection. 
In reality, though, the gradient is rarely so complete. The gradient stabilizes when the effects of thermal diffusion are balanced by the effects of turbulent mixing and concentration-driven diffusion. This favors long, narrow columns, with high with large thermal gradients and large mass differences between species.

A schematic of the project cask in shown in Figure A-10, showing the expected convection pattern (H. Adkins, personal communication). The basket extends the length of the cask, with a 1-2" gap at the top. There are acruate drainage slots, 0.4 " high, cut into the bottom of each cell divider; there are larger slots in four locations for the basket lifting device. There are hollow spacers, or alignment rails, between the basket and the inner wall of the cask, which are open at the top but closed at the bottom; when the cask is drained, the water exits the spacers through bolt-holes and gaps between the plates. Heat is lost mostly from the sides and top of the cask, so convection is up through the central basket cells, and down through the cells on the edge of the basket. Because the hollow rails are blocked, they do not participate in the global convection in the cask

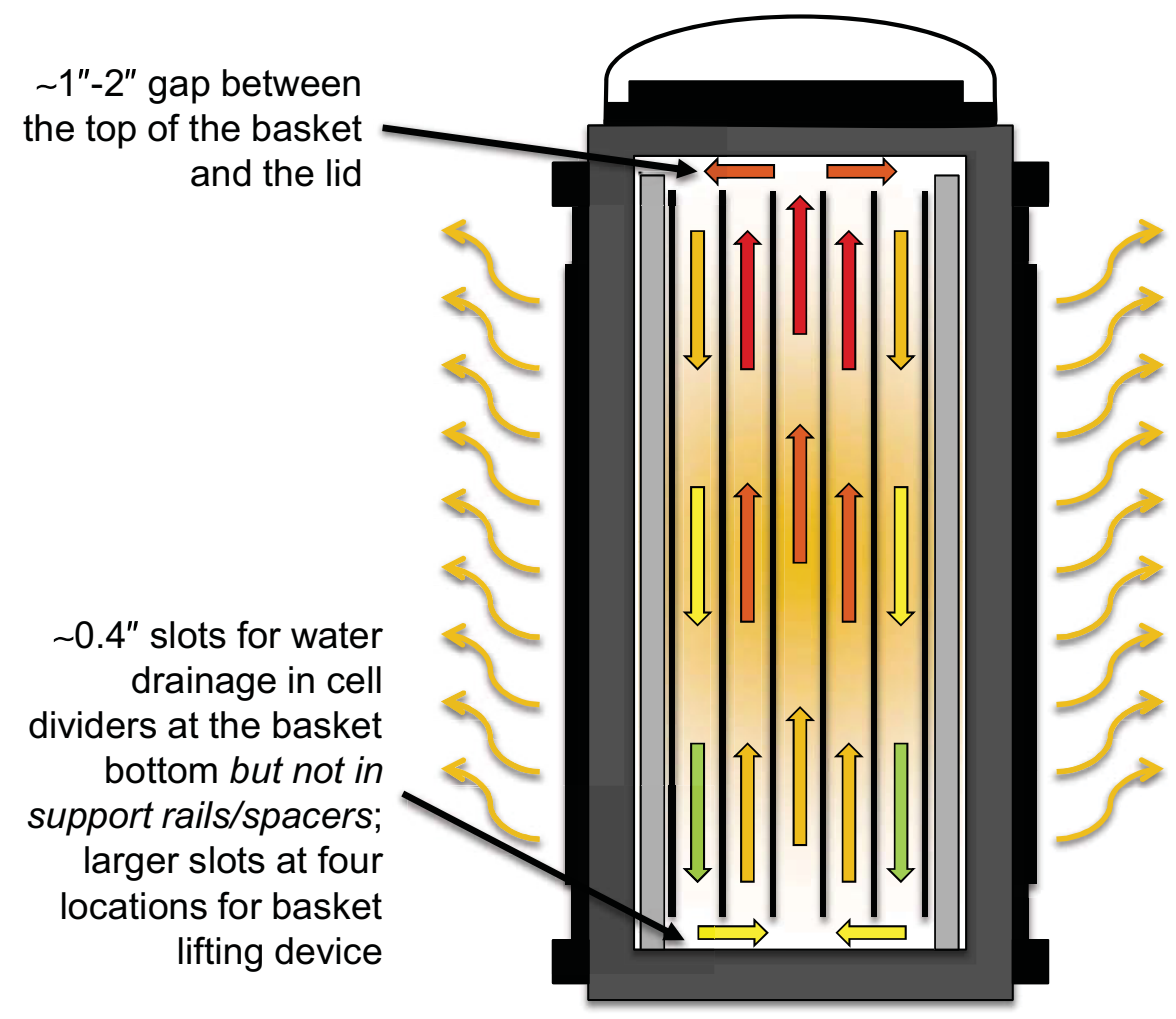

Figure A-10. Schematic of the project cask, showing predicted convection pattern.

In a general sense, the cask resembles a Clusius-Dickel column, with a central heat source, and heat being lost on the sides, producing a convection cell with a rising limb in the center, and falling limbs on the sides. However, there is one major difference. The Clusius-Dickel column is a counterflow system, with the rising and falling limbs passing each other and exchanging gas species via thermal diffusion. In the project cask, the rising and falling limbs are separated by basket walls, which are not perforated-diffusive equilibration is not possible (Figure A-11). Without exchange driven by thermal diffusion, convection serves only to mix the system in the cask, not to drive gas separation. It is unlikely that global circulation within the cask could result in enhanced separation of $\mathrm{He}$ and $\mathrm{Kr}$.

However, isolated convection cells may form within the hollow spacer rails, transferring heat between the basket and the walls of the cask. Thermal separation could occur within the rails, with Kr concentrating at the bottom, if the volume were truly closed. However, if water drainage can occur through the bolt-holes 
and gaps, then certainly, any dense gas phase collecting in the rails would leak out and mix with the bulk gas in the cask.

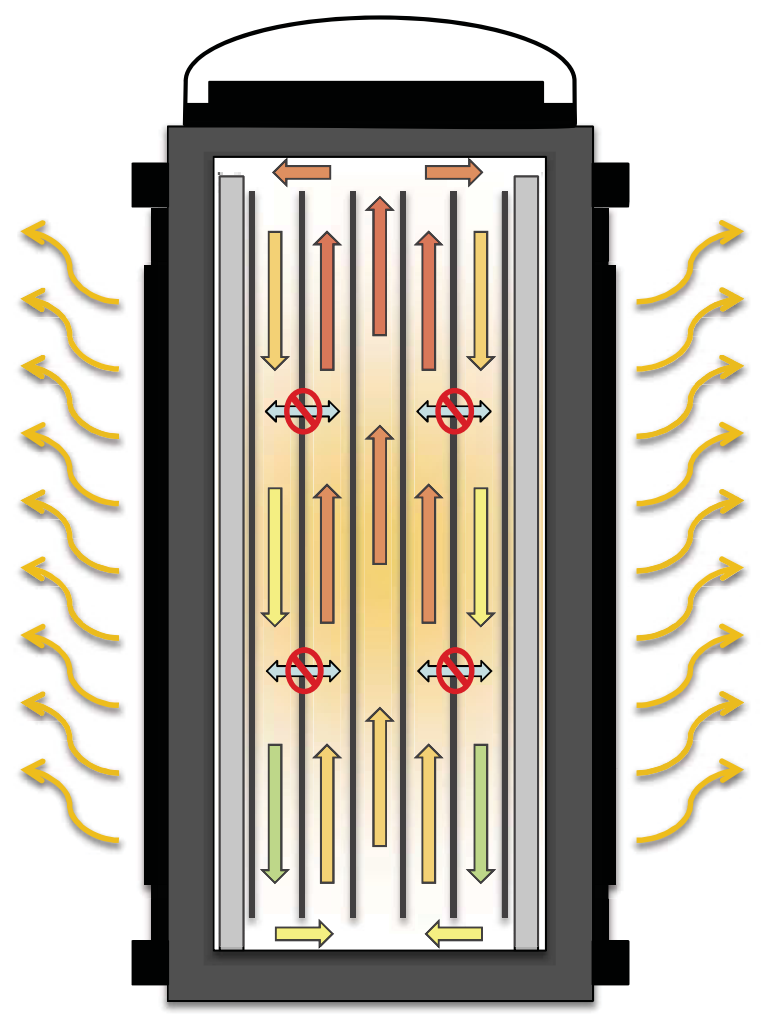

Figure A-11. Cask schematic, showing that basket walls prevent diffusive exchange between the rising and falling arms of the convection cell.

\section{A-4. Summary}

Gases from the project cask will be sampled to determine if rod failure has resulted in the release of ${ }^{85} \mathrm{Kr}$. Sampling will be accomplished through a vent opening into the top of the cask, and the concern has been raised that $\mathrm{Kr}$ could segregate into the bottom of the cask, interfering with detection. Here, the possibility of density-driven segregation is evaluated and eliminated. Buoyancy effects are negligible relative to the effects of diffusive mixing; $\mathrm{Kr}$ will neither settle out of a $\mathrm{He}-\mathrm{Kr}$ gas mixture nor remain unmixed at the bottom of the cask, if it is released and flows there as a density flow.

Thermal diffusion also cannot result in significant segregation. Although $\mathrm{He}$ and $\mathrm{Kr}$ differ greatly in mass, thermal variability within the cask is relatively small, and separation is greatly inhibited by very low concentrations of $\mathrm{Kr}$ relative to He; thermal separation is most effective when the two gas species are present in similar amounts. While convection can greatly enhance separation by thermal diffusion in ideal systems, the geometry of the cask/basket system prevents this from occurring in the project cask. The rising and falling arms of the convection cell are separated by the basket compartment walls, preventing the diffusive exchange necessary to result in the development of a vertical gradient in gas composition.

For all of these reasons, sampling the gas phase from the top of the project cask is unlikely to affect the ability to sample and detect ${ }^{85} \mathrm{Kr}$. 